\title{
Estimating Peak Discharges Of Small, Rural Streams In Massachusetts
}

\section{United States Geological Survey Water-Supply Paper 2214}

Prepared in cooperation with the Massachusetts Department of Public Works and the U.S. Department of Transportation Federal Highway Administration

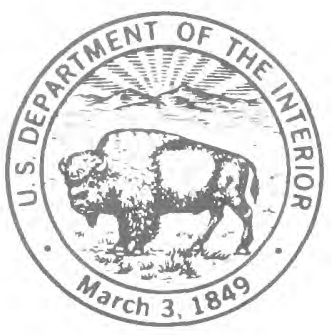




\section{Estimating Peak Discharges Of Small, Rural Streams In Massachusetts}

By S. WILLIAM WANDLE, JR.

Prepared in cooperation with the Massachusetts Department of Public Works and the U.S. Department of Transportation Federal Highway Administration

The opinions, findings, and conclusions expressed in this report are not necessarily those of the Federal Highway Administration. 


\section{UNITED STATES DEPARTMENT OF THE INTERIOR}

JAMES G. WATT, Secretary

GEOLOGICAL SURVEY

Dallas L. Peck, Director

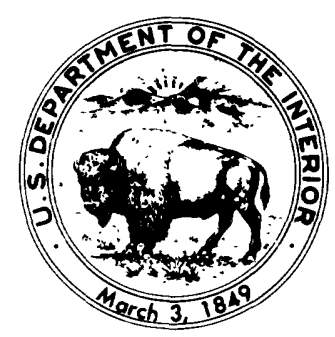

For sale by Distribution Branch

Text Products Section

U.S. Geological Survey

604 South Pickett Street

Alexandria, Virginia 22304

Lil:rary of Congress catalog-card No. 83-600546 


\title{
CONTENTS
}

\author{
Glossary IV \\ Abstract 1 \\ Introduction 1 \\ Acknowledgments 2 \\ Limitations of method 2 \\ Summary of estimating techniques 2 \\ Ungaged sites 5 \\ Gaged sites 5 \\ Sites on gaged streams 5 \\ Computation of independent variables 9 \\ Accuracy 10 \\ Examples 10 \\ Ungaged site 10 \\ Gaged site 10 \\ Site on gaged stream 13 \\ Rainfall-runoff model description 14 \\ Data collection 16 \\ Data analysis 17 \\ Analytical techniques 17 \\ Calibration of the rainfall-runoff model 17 \\ Peak discharge synthesis and frequency 18 \\ Station floodflow frequency 18 \\ Regional regression analysis 20 \\ Data network 21 \\ Multiple-regression analysis 21 \\ Discussion and recommendations 22 \\ Selected references 23
}

\section{FIGURES}

1. Map showing study area and generalized skew coefficient 3

2. Map showing location of gaging stations 4

3. Flow chart of peak discharge estimating procedure 11

4-6. Graph of observed and estimated peak discharges in the

4. Eastern region 12

5. Central region 13

6. Western region 14

7. Schematic outline of the rainfall-runoff model 15

8. Flood-frequency curves for Walker Brook near Becket Center, Mass. 20

\section{TABLES}

1. Extremes of basin characteristics in base-data network 2

2-4. Selected basin and flood characteristics for stations in the

2. Eastern region 6

3. Central region 7

4. Western region 8

5. Equivalent years of record 9

6. Regional exponent to transfer flood peaks on a gaged stream 9

7. The 10 rainfall-runoff model parameters 16

8. Summary of calibrated model parameters 19

9. Summary of flood-frequency relations for the eight modeled stations 23

10. Summary of preliminary estimating relations 24 


\section{GLOSSARY}

Annual peak discharge The maximum instantaneous discharge occurring during the water year.

Drainage area The drainage area of a stream at a specified location is that area measured in a horizontal plane and enclosed by a topographic divide.

Exceedance probability The percent chance, in any 1-year period that the annual peak discharge will exceed a specified magnitude. The reciprocal of recurrence interval.

Flood or peak discharge The maximum rate of flow, in cubic feet per second, that occurred during a flood.

Gaging station A particular site on a stream where systematic observations of gage height or discharge are obtained.

Multiple-regression analysis A statistical technique by which a relation between a dependent variable and two or more independent variables is derived.

Recurrence interval The average interval of time, in years, within which a given flood will be exceeded once. The reciprocal of exceedance probability.

Regulated stream A stream that has been subjected to control by reservoirs, diversions, or other man-made hydraulic structures.

Skew coefficient A numerical measure or index of the lack of symmetry in a frequency distribution. The term indicates the positive or negative curvature of a flood-frequency relation.

Standard error of estimate The standard deviation, adjusted for degrees of freedom, of the residual errors (differences between observed and computed values) about regression relation used to predict the dependent variable. Approximately two-thirds of data values are included within one standard error of estimate assuming the errors are normally distributed.

Usable storage The volume normally available for release from a reservoir, lake, or pond. This volume excludes the dead storage which is the volume below the lowest controllable level. 


\section{Estimating Peak Discharges of Small, Rural Streams in Massachusetts}

\author{
By S. William Wandle, Jr.
}

\section{Abstract}

Floodflows on natural-flow streams in Massachusetts with drainage areas between 0.25 square miles and 260 square miles may be estimated from drainage area, main-channel slope, mean basin elevation, and the area of swamps, lakes, and ponds. Multiple-regression techniques were used to define the relationship between a suite of basin and climatic characteristics and flood peaks in three flood-frequency regions at a total of 95 sites. Station flood-frequency data were computed following guidelines in Bulletin 17A of the U.S. Water Resources Council. The frequency analyses are based upon weighted skew values, adjustments for high and low outliers, and historic peak data.

Regression equations for estimation of peak discharges for $0.5,0.2,0.1,0.04,0.02$, and 0.01 exceedance probabilities are provided for ungaged sites. An improved sample of flood peaks and gaging stations and the definition of three flood-frequency regions reduced the standard errors of estimate by about 5 percent over those for the 1977 relations. Included in this analysis were the synthetic flood-frequency data at 8 sites computed using historic climatic data and 10 parameters optimized by calibration of the U.S. Geological Survey's rainfall-runoff model with storm data observed over 11 years.

The equations are applicable to streams unaffected by regulation where the usable manmade storage is less than 4.5 million cubic feet per square mile, or by diversions or urbanization. The equations are restricted to sites where the basin indices are within a specified range outside of eastern Plymouth, Barnstable, Dukes, or Nantucket Counties. In these areas, the available data do not adequately define the influence of high infiltration and storage capacities of drainage basins on floodflows.

\section{INTRODUCTION}

Information on the magnitude and frequency of floods that may occur is necessary for the economic design of riverine structures. Prior to 1960 there was a deficiency of flood data for culvert-size streams. In response to this need, a study was begun in 1962 in cooperation with the Massachusetts Department of Public Works and the Federal Highway Administration to define the streamflow characteristics of small, rural streams draining less than $10 \mathrm{mi}^{2}$. The objective of this research study is to provide the highway engineer with a technique for estimating peak discharges on small, rural and ungaged streams in Massachusetts.
This is the fourth and final report on estimating the magnitude and frequency of floods on small, rural Massachusetts streams. The purpose of this report is to present the results of application of the U.S. Geological Survey rainfall-runoff model and to reassess previous floodestimating relations in Wandle (1977).

This report fulfills the requirements of project R-9-0, "Small Watersheds Research Study" sponsored by the Massachusetts Department of Public Works, Research and Materials Division. This study was financed under the Highway Research Program sponsored by the U.S. Department of Transportation, Federal Highway Administration.

The estimating techniques presented herein should be used in preference to the earlier methods developed by Knox and Johnson (1965), Johnson and Laraway (written commun., 1971), Johnson and Tasker (1974), and Wandle (1977). An improved sample of stations under $10 \mathrm{mi}^{2}$, a longer array of flood peaks, and the rainfall-runoff modeling results were available for this analysis. Guidelines recommended by the U.S. Water Resources Council (1977) were used in the station-frequency determination. By dividing the study area into three flood-frequency regions, an improved understanding of the statewide floodflow variation was gained.

Floodflow data, except for data from two long-term gaging stations, for Massachusetts streams draining less than $10 \mathrm{mi}^{2}$ have been collected for this project. Flood peak data on the larger river basins have been collected for many years as part of cooperative programs with various State and Federal agencies. The long-term Rochester, Mass., daily evaporation and Boston, Mass., daily rainfall with storm precipitation reductions to 5-minute unit values, were obtained from U.S. Department of Commerce, National Oceanic and Atmospheric Administration.

The final results of this study are given in the section "Summary of Estimating Techniques." This material is presented in the beginning of the report to aid the designer. The methodology is provided in equation form to estimate peak discharges on natural-flow streams at ungaged sites, gaged sites, or sites on a gaged stream. Examples are given to assist in applying these equations. The user should be aware of conditions under which the estimating relations are not applicable. The limitations of the estimating relations are discussed prior to the estimating techniques. In subsequent sections, the technical details are discussed including selection of the data base, computation of the station flood-frequency curves, evalua- 
tion of basin and climatic characteristics, and the multipleregression analysis. The U.S. Geological Survey's rainfall-runoff model and its application to extend short-term flood records are also discussed.

\section{ACKNOWLEDGMENTS}

The author thanks the many persons who have kindly given time, information, and guidance during this study. Particular thanks are given to the late Carl G. Johnson, project chief prior to 1975 , and to other persons in the Geological Survey who assisted in the data collection and in the preparation of this report.

\section{LIMITATIONS OF METHOD}

The estimating relations do not apply to streams where the floodflows are significantly affected by regulation, diversions, or urbanization and where the usable manmade storage is over 4.5 million cubic feet (103 acrefeet) per square mile. Even though the unit storage is less than that specified, the estimating equations do not apply to locations just below a reservoir of any size. These equations should not be used to estimate flood peaks for streams on Cape Cod, Martha's Vineyard, or Nantucket, or streams in the eastern part of Plymouth County as indicated in figure 1; sufficient data are not available to adequately define the influence of the high infiltration and storage capacities of drainage basins on flood characteristics in these areas.

The flood-estimating equations are applicable to ungaged sites with basin and climatic characteristics similar to the characteristics of the data base used to develop these relations. Therefore, the estimating relations apply only to streams in Massachusetts where floodflows are essentially natural and where the drainage area, slope, storage, and elevation indices are within the range of values listed in table 1 .

\section{SUMMARY OF ESTIMATING TECHNIQUES}

A systematic peak-flow record is not always available where floodflow estimates are needed for design purposes. Regional regression equations relating flood peaks to easily measured basin and climatic characteristics are useful in transferring observed floodflow information from a set of stations to the ungaged site. The peak discharge from the station frequency curve and the regression equation are weighted to obtain an estimate of flood peaks for those design sites located at a gaging station. This weighted peak flow can be transferred upstream or downstream by using a drainage area adjustment factor for design sites on the same stream as a gaging station.

The designer should follow the procedures outlined below to obtain floodflow estimates on natural-flow streams in Massachusetts.

1. Locate the site of interest in figure 2 and select the regional flood equations, 1-18, to use.

2. From tables 2,3 , and 4 , and figure 2 , determine if the study site is located at a gaged site or on a gaged stream. Refer to U.S. Geological Survey (1975) for additional information on the location of gaging stations and crest-stage gage partial-record stations.

3. Compute the appropriate basin characteristics including an estimate of the usable manmade storage in the basin. Decide if the criteria for application of the formulas are satisfied using information from the section "Limitations of Method."

4. If the study site is located at a gaged site given in tables $2-4$, use the method for "Gaged Sites."

5. If the study site is located on a gaged stream and the drainage area ratio is within the allowable limits, use the method "Sites on Gaged Streams."

6. If the study site is not located at or near a gaged site, use the method "Ungaged Sites." A flow chart of the estimating procedure is given in figure 3 .

Table 1. Extremes of basin characteristics in base-data network

[NA, Not Applicable to estimating method in this region]

$\begin{array}{cccc}\begin{array}{c}\text { Drainage } \\ \text { area } \\ \left(\mathrm{mi}^{2}\right)\end{array} & \begin{array}{c}\text { Main-channel } \\ \text { slope } \\ (\mathrm{ft} / \mathrm{mi})\end{array} & \begin{array}{c}\text { Storage } \\ \text { (percent) }\end{array} & \begin{array}{c}\text { Mean basin } \\ \text { elevation } \\ \text { (feet) }\end{array}\end{array}$

\begin{tabular}{|c|c|c|c|c|}
\hline \multicolumn{5}{|c|}{ Eastern Massachusetts region } \\
\hline Maximum & 260 & NA & NA & NA \\
\hline 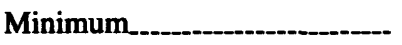 & .25 & NA & NA & NA \\
\hline \multicolumn{5}{|c|}{ Central Massachusetts region } \\
\hline Maximum & 199 & NA & 22.7 & NA \\
\hline 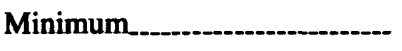 & .49 & NA & 0 & NA \\
\hline \multicolumn{5}{|c|}{ Western Massachusetts region } \\
\hline Maximum & 162 & 449 & NA & 1900 \\
\hline Minimum & .27 & 4.74 & NA & 400 \\
\hline
\end{tabular}




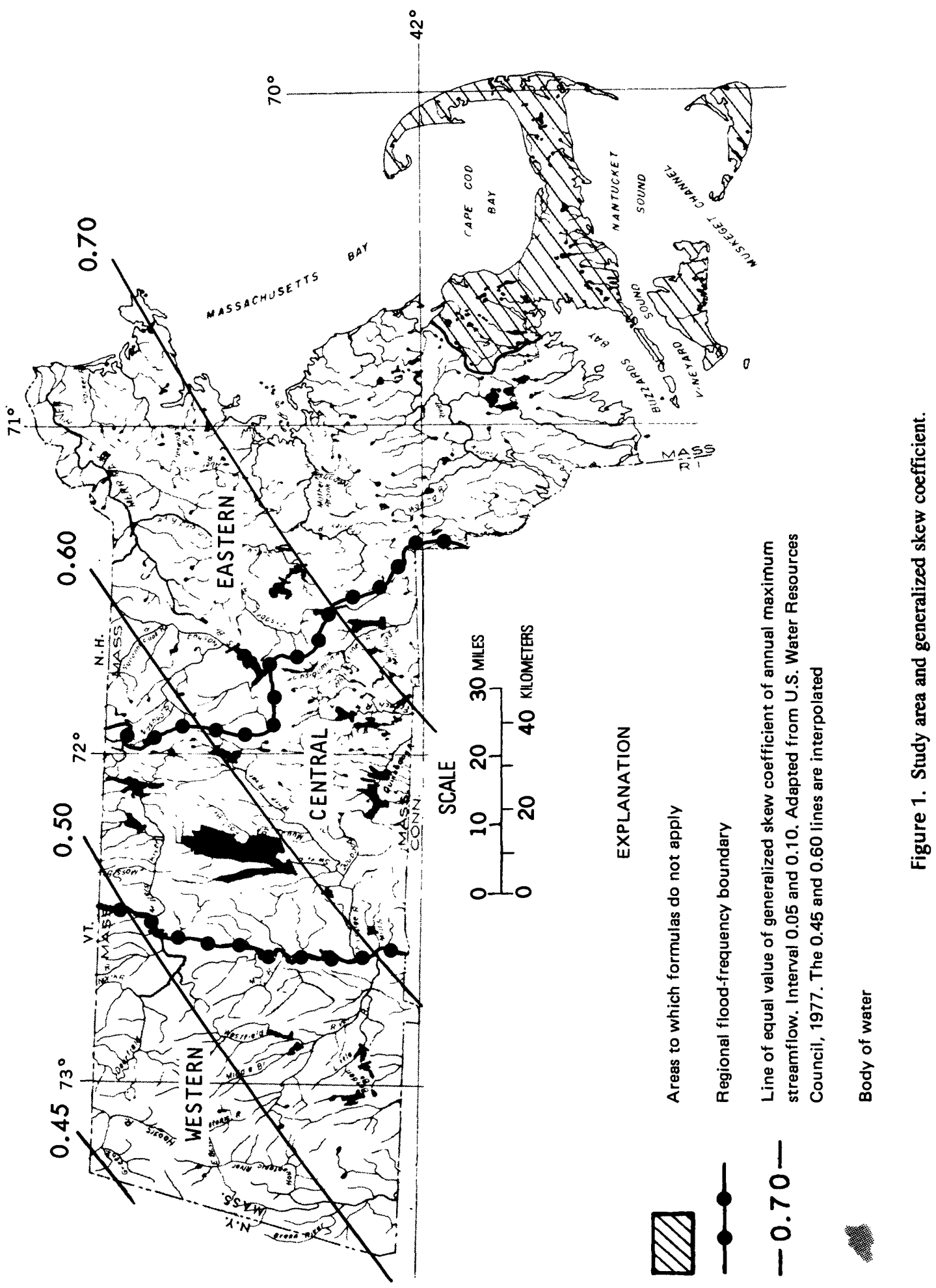




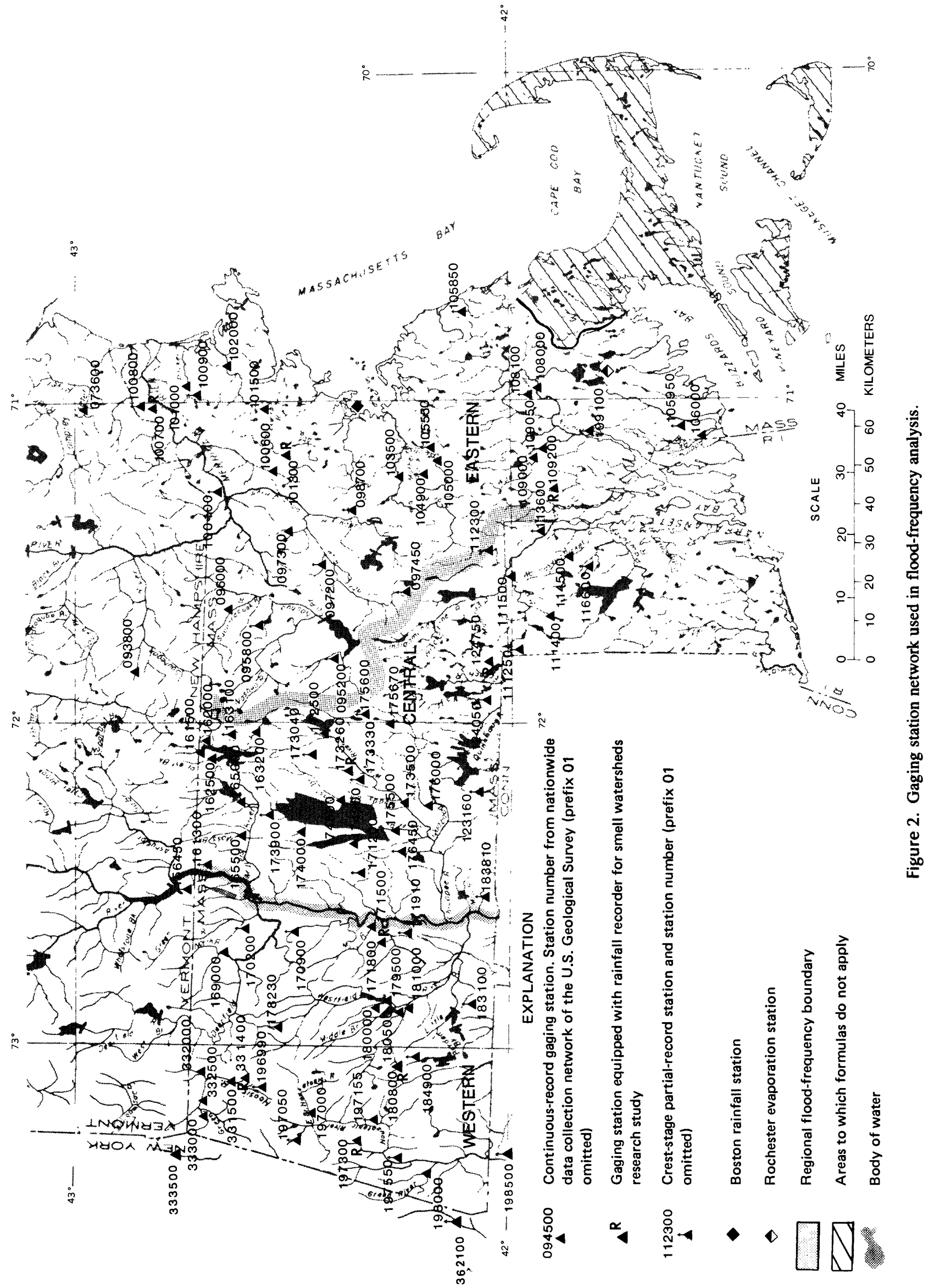




\section{Ungaged Sites}

Multiple-regression techniques were used to relate annual peak discharges at gaged sites to a suite of basin characteristics. It was found that the floodflow variation could best be explained by separating the State into three flood-frequency regions. The equations given below provide the best estimate of peak discharges corresponding to the $0.5,0.2,0.1,0.04,0.02$, and 0.01 exceedance probabilities. (The 2-, 5-, 10-, 25-, 50-, and 100-year recurrence intervals, respectively.) These flood-estimating equations are applicable to those sites satisfying the criteria in "Limitations of Method."

Eastern Massachusetts

Merrimack River basin

Coastal river basins (Parker River to Ten Mile River excluding basins in eastern Plymouth County)

\begin{tabular}{|c|}
\hline $\begin{array}{l}\text { Average standard error } \\
\text { (percent) }\end{array}$ \\
\hline 49 \\
\hline 45 \\
\hline 44 \\
\hline 46 \\
\hline 48 \\
\hline 52 \\
\hline
\end{tabular}

$Q_{0.5}=36.30 A^{0.682}$

$Q_{0.2}=55.38 A^{0.670}$

$Q_{0.1}=72.12 A^{0.660}$

$Q_{0.04}=96.71 A^{0.651}$

$Q_{0.01}=143.1 A^{0.638}$

\section{Central Massachusetts}

Blackstone River basin

French River basin

Quinebaug River basin

Millers River basin

Chicopee River basin and minor basins draining into the Connecticut River from the east side.

Average standard error (percent)

$\begin{array}{ll}Q_{0.51}=41.11 A^{0.743} S t^{-0.097} & 25 \\ Q_{0.21}=65.17 A^{0.751} S t^{-0.139} & 28 \\ Q_{0.11}=84.98 A^{0.760} S t^{-0.166} & 30 \\ Q_{0.04}=114.9 A^{0.775} S t^{-0.195} & 34 \\ Q_{0.02}=141.9 A^{0.785} S t^{-0.217} & 38 \\ Q_{0.01}=172.7 A^{0.797} S t^{-0.237} & 41\end{array}$

\section{Western Massachusetts}

Deerfield River basin

Westfield River basin and minor basins draining into the Connecticut River from the west.

Housatonic River basin

Hoosic River basin

$Q_{0.51}=0.933 A^{0.970} S l^{0.158} E^{0.429}$
$Q_{0.21}=1.05 A^{0.969} S l^{0.178} E^{0.469}$
$Q_{0.11}=1.23 A^{0.969} S l^{0.187} E^{0.480}$

where

$Q_{t}$ is the peak discharge, in cubic feet per second, for the specified exceedance probability, $t$,

$A$ is the drainage area, in square miles,

$S l$ is the main-channel slope, in feet per mile,

$S t$ is the storage index which is the area of swamps, lakes, and ponds expressed as a percentage plus 0.5 , and

$E \quad$ is the mean basin elevation, in feet.

The flood-frequency regional boundaries are delineated in figures 1 and 2 . Independent variables used in the flood-estimating equations are determined as indicated in the section "Computation of Independent Variables" from U.S. Geological Survey 1:24,000 topographic quadrangles.

\section{Gaged sites}

Basic flood information on natural streams and on regulated streams prior to significant regulation is given in tables 2,3 , and 4 . The recommended value for use is the weighted average discharge computed from the observed station value and from the appropriate flood-estimating equation to reduce the time-sampling error. The station record may represent a period of high or low streamflow sequences and, consequently, the short-term records for the small streams may contain a large sample error. The weighted average discharge is computed from the equation:

$$
Q_{t(w)}=\frac{\left(Q_{t(s)} \times N\right)+\left(Q_{t(r)} \times E\right)}{N+E}
$$

where

$Q_{t(w)}$ is the weighted discharge for exceedance probability, $t$,

$Q_{t(s)}$ is the station value given in tables 2,3 , and 4 for the peak at exceedance probability, $t$,

$Q_{t(r)}$ is the flood-peak estimate at exceedance probability, $t$, from the regression equations,

$N \quad$ is the number of years of observed peak data, given in tables 2,3 , and 4 , used to compute the station frequency curve (the greater of the observed and historic periods), and

$E$ is the equivalent years of record for the flood-estimating equations listed in table 5 .

\section{Sites on Gaged Streams}

Experience indicates that flood-frequency information from a gaged site is easily transferred upstream or downstream on the basis of the drainage area ratio between the ungaged and gaged sites raised to a power less than one. The relationship between the ratios of drainage area to peak discharges on the same stream was defined by equating the station-flood peaks to drainage area and averaging the resulting exponents in each region. The ex- 


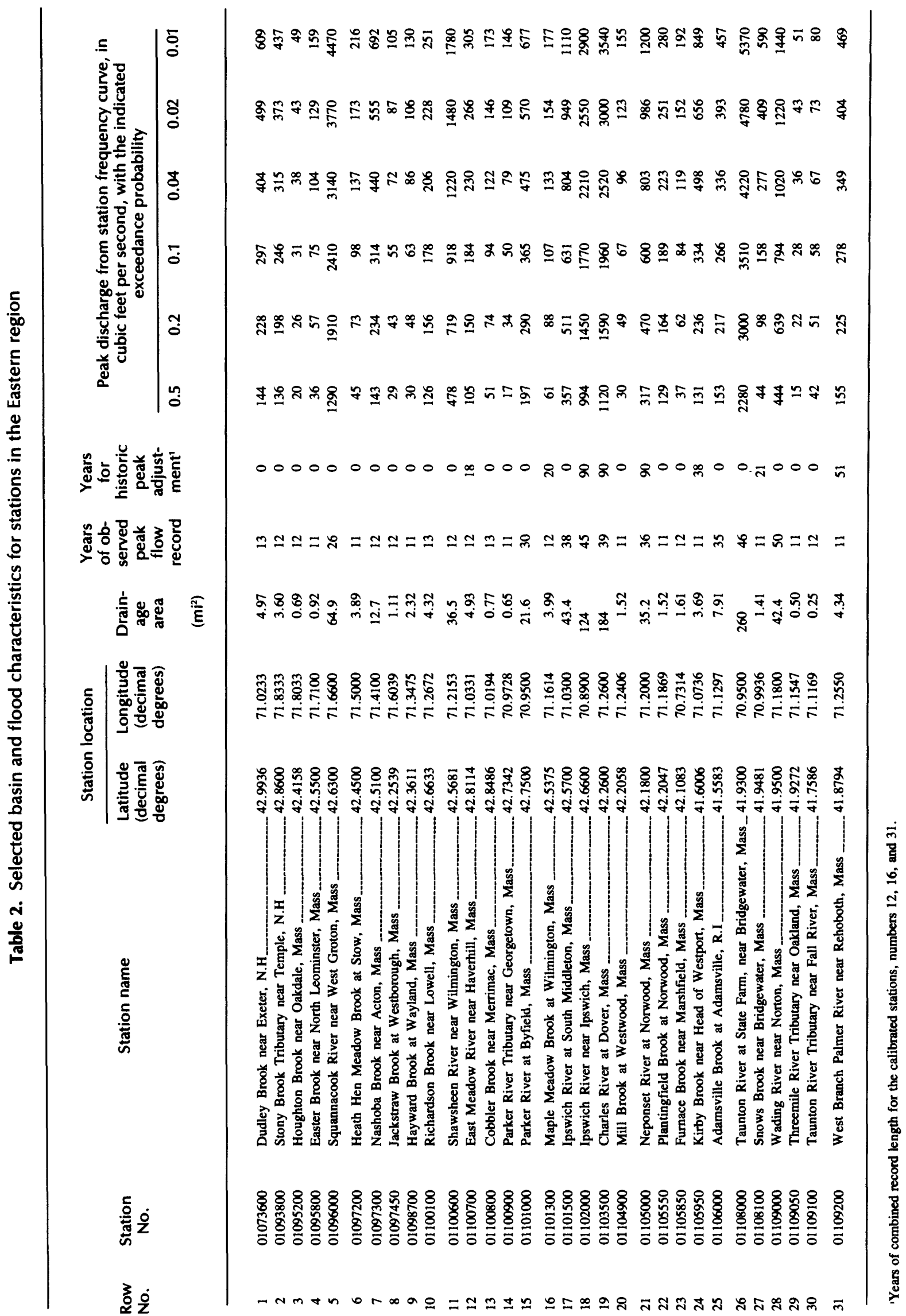




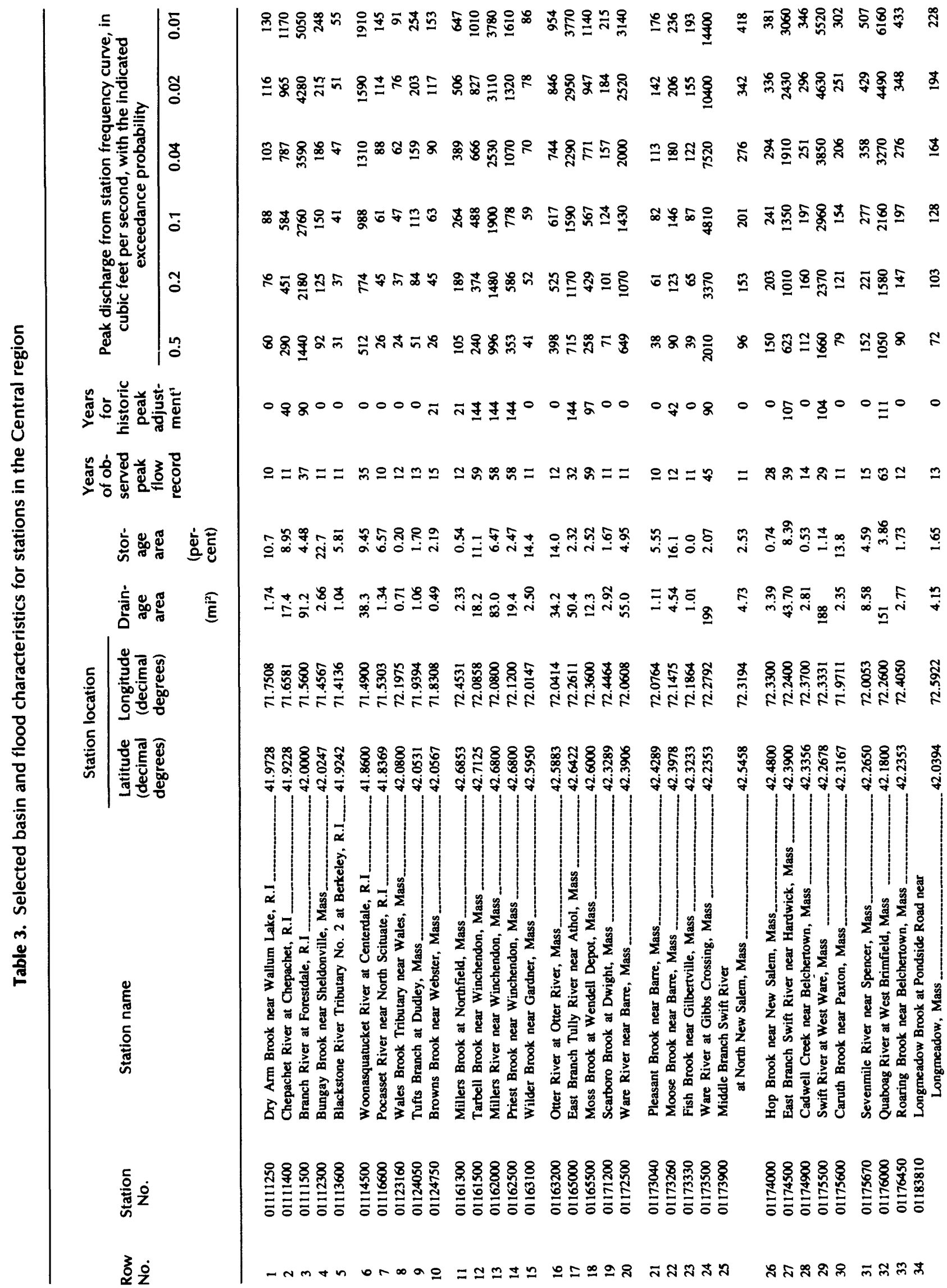

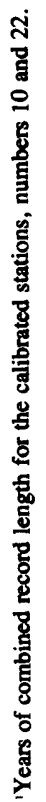




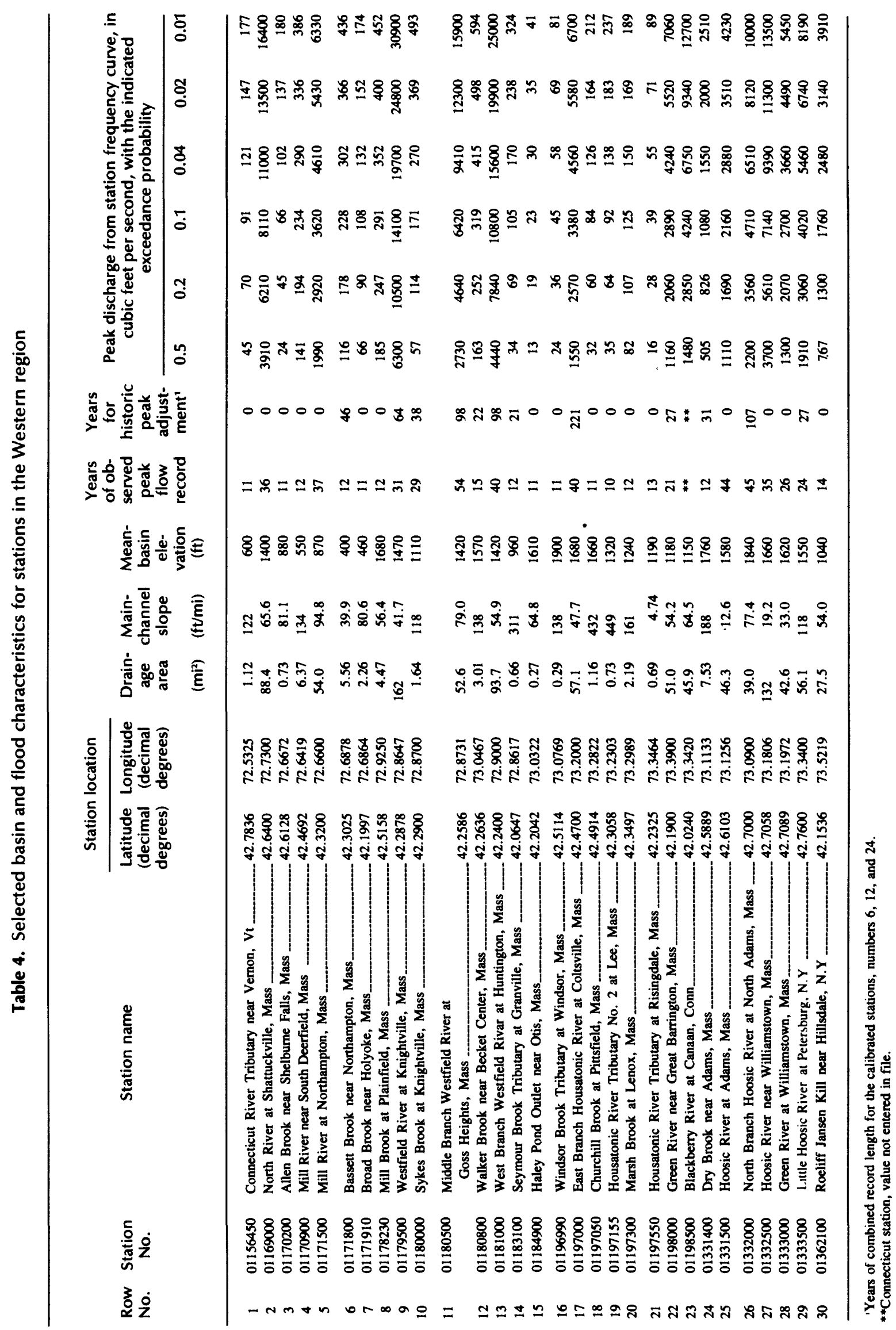


Table 5. Equivalent years of record

\begin{tabular}{cccc}
\hline $\begin{array}{c}\text { Exceedance } \\
\text { probability }\end{array}$ & $\begin{array}{c}\text { Eastern } \\
\text { region }\end{array}$ & $\begin{array}{c}\text { Central } \\
\text { region }\end{array}$ & $\begin{array}{c}\text { Western } \\
\text { region }\end{array}$ \\
\hline & & 9 & 10 \\
0.04 & 5 & 11 & 10 \\
.02 & 6 & 11 & 10 \\
.01 & 7 & & \\
\hline
\end{tabular}

ponents ( $x$ ) to adjust peak discharges on the same stream for differences in drainage area are given in table 6 for each region.

If the site of interest is located on a gaged stream used in the multiple-regression analysis, flood estimates are computed using equation 20 . This procedure is generally applicable for ungaged sites where the drainage area ratio of the ungaged site to the gaged site, $A_{u} / A_{g}$, lies between about 0.6 and 1.4 .

where

$$
Q_{t(u)}=\left(\frac{A_{u}}{A_{g}}\right)^{x} Q_{t(g)}
$$

$Q_{t(u)}$ is the peak discharge at ungaged site for exceedance probability, $t$,

$Q_{t(g)}$ is the weighted average discharge at gaged site for exceedance probability, $t$, computed using equation 19 ,

$A_{u} \quad$ is the drainage area of ungaged site,

$A_{g} \quad$ is the drainage area of gaged site, and

$x \quad$ is the exponent for each flood region.

Table 6. Regional exponent to transfer flood peaks on a gaged stream either upstream or downstream

Flood region

\begin{tabular}{lr}
\hline Eastern Massachusetts & 0.66 \\
Central Massachusetts & .75 \\
Western Massachusetts & .96
\end{tabular}

\section{Computation of Independent Variables}

A rough estimate of the amount of usable manmade storage can be made by using the surface area and drawdowns of controlled lakes and ponds in the drainage basin as shown on topographic quadrangle maps. Data on surface area and dam height for many lakes and ponds are presented in the series of reports on reservoir sites by major river basin (U.S. Department of Agriculture, 196876; Massachusetts Department of Environmental Management, 1979a, 1979b). Other sources of information on dams include the various inventories of dams prepared by Federal, State, and County agencies. A field inspection may be required to obtain the drawdown data.
The climatic and basin characteristics for drainage area, main-channel slope, mean basin elevation, and area of swamps, lakes, and ponds should be determined by the following methods or by methods of equivalent accuracy: (Topographic quadrangle maps at a scale of 1:24,000 are to be used whenever possible to determine the basin characteristics.)

1. Drainage area. Trace drainage area boundary lines on topographic maps along divides indicated by contour elevations, starting at the point on the stream for which the drainage area is desired. Interpolation between contours may be indicated by reference to trails, old roads, or firebreaks in forested areas, all of which frequently follow drainage divides. Also, detailed information may be obtained from highway or street profiles, from examination of aerial photographs, and from ground reconnaissance. The outlined drainage area is traced with a planimeter to obtain the drainage area in square miles.

2. Main-channel slope. Outline the main channel on a map of the basin. Upstream from each stream junction point, choose the main channel as the stream that drains the most area. Continue the main channel to the drainage basin divide beyond the upstream end of the stream line shown on the map by drawing flow lines indicated by contours. Measure the total length by a map measurer or set of dividers set to one tenth of a mile, locate the points 85 and 10 percent of the total length above the point of interest on the stream, and determine the elevation of these points. The main-channel slope is computed as the difference in elevation in feet divided by the length in miles between the two points.

3. Area of swamps, lakes, and ponds. For ease of measurement, the boundary of the swamp area is drawn to just enclose the area within the drainage basin defined by the swamp symbols. The surface area of swamps, lakes, and ponds is measured by using the planimeter or a transparent grid. Randomly place the grid over the water and swamp area and count the squares or, if the water and swamp area is large enough (about 30 squares), count the number of grid intersections within the surface area of swamps, lakes, and ponds; from a knowledge of the area of the grid, the area of swamps, lakes, and ponds in square miles may be determined. The storage area is the total area of all the swamps, lakes, and ponds expressed as a percentage of the total drainage area to the nearest 0.1 percent. The storage index, as used in the equations, is computed by adding a factor of 0.5 percent to the value for storage area.

4. Mean basin elevation. A transparent grid is placed over a topographic map of the river basin and the mean elevation of all the elevations under each grid intersection is computed. The grid spacing is selected to 
provide at least 25 intersections within the basin boundary.

\section{Accuracy}

The accuracy of regression may be expressed as the standard error of estimate or as the equivalent years of record. Standard error of estimate is a measure of how well the peaks computed from the regression equation agree with the observed flood peaks. The regression value is within the range of error (standard error of estimate) at about 2 out of 3 sites and is within twice this range at about 19 out of 20 sites. Equivalent years of record is the number of actual years of streamflow records required at the ungaged site to provide an estimate equal in accuracy to the regression estimate.

The equivalent record length, computed after Hardison (1971), is indicated for selected exceedance probabilities in table 5 . Flood peaks computed from the station flood-frequency curves at the $\mathbf{0 . 0 2}$ exceedance probability are plotted against the regression estimates for each region in figures $4-6$.

Johnson and Tasker (1974) developed the first flood-peak estimating relations based upon a large sample of small-streams data. Equations in Johnson and Tasker (1974), Wandle (1977), and in this report used similar sets of small-streams data. The standard errors for the 1977 relations were reduced by about 10 percent of those for the 1974 equations. The standard errors of estimate for the final estimating relations in this report are improved by about 5 percent over those for the 1977 equations. This further reduction in the standard error estimate is the result of a combination of several factors. Swamp area was included in the storage index and the flood-frequency curves were adjusted, where necessary, for high outlier events. Dividing the State into three regions with similar flood characteristics minimized the unexplained error. Stations with a questionable stage-discharge relationship during high flow were eliminated from the analysis. The synthetic flood-frequency curves for eight stations, obtained from calibration of the rainfall-runoff model, may have minimized the time-sampling error at these sites.

\section{Examples}

The following examples illustrate the methodology to obtain peak discharge estimates on natural-flow streams in Massachusetts at ungaged sites, gaged sites, or sites on a gaged stream. The procedures in the "Summary of Estimating Techniques" section provide the criteria for selecting the appropriate method. The user is cautioned to be aware of the limitations placed on these methods.

\section{Ungaged Site}

Given: Compute the 0.02 exceedance probability flood for an ungaged site with the following indices measured as described in the "Computation of Independent Variables" section.

Drainage area $=13.5 \mathrm{mi}^{2}$

Main-channel length $=7.5$ miles

Area of swamps, lakes, and ponds $=1.4 \mathrm{mi}^{2}$

Mean basin elevation $=560$ feet

Next, the main-channel slope and storage index are computed.

Main-channel slope:

From the appropriate topographic quadrangle map, the elevation of the main channel at mile $0.8(7.5 \times 0.10)$ is 480 feet and at mile 6.4 $(7.5 \times 0.85)$ is 840 feet. The main-channel slope is computed by dividing the difference in elevation by the distance between the two points:

$$
\text { Main-channel slope }=\frac{840-480}{6.4-0.8}=64.3 \mathrm{ft} / \mathrm{mi}
$$

Storage index:

The area of swamps, lakes, and ponds in the drainage basin is expressed as a percentage of the drainage area and then increased by 0.5 percent.

$$
\begin{aligned}
& \text { Storage area }=\frac{1.4}{13.5}=0.1037 \text { or } 10.4 \text { percent } \\
& \text { Storage index }=10.4+0.5=10.9 \text { percent }
\end{aligned}
$$

After computation of the required independent variables, the user should check the limiting values of these characteristics and ensure that the usable manmade storage in the basin is less than $4.5 \mathrm{M} \mathrm{ft}^{3} / \mathrm{mi}^{2}$.

If this site is located in the Eastern Massachusetts flood-frequency region, then the estimated peak discharge is computed using equation 5 as follows:

$$
\begin{aligned}
50-\mathrm{yr} \text { peak } & =Q_{0.02}=118.1 A^{0.645} \\
& =118.1(13.5)^{0.645} \\
& =633 \mathrm{ft}^{3} / \mathrm{s}
\end{aligned}
$$

If this site is located in the Central Massachusetts flood-frequency region, the estimated peak discharge is computed using equation 11 as follows:

$$
\begin{aligned}
50-\mathrm{yr} \text { peak } & =Q_{0.02}=141.9 A^{0.785} S t t^{-0.217} \\
& =141.9(13.5)^{0.785}(10.9)^{-0.217} \\
& =652 \mathrm{ft}^{3} / \mathrm{s}
\end{aligned}
$$

If this site is located in the Western Massachusetts flood-frequency region, the estimated peak discharge is computed using equation 17 as follows:

$$
\begin{aligned}
50 \text {-yr peak } & =Q_{0.02}=1.41 A^{0.970} S l^{0.215} E^{0.520} \\
& =1.41(13.5)^{0.970}(64.3)^{0.215}(560)^{0.520} \\
& =1,160 \mathrm{ft}^{3} / \mathrm{s}
\end{aligned}
$$

Gaged site

Given: Compute the best estimate of 0.02 exceedance probability flood on Fish Brook on Goddard Road in Gilbertville (lat $42^{\circ} 19^{\prime} 24^{\prime \prime}$, long $72^{\circ} 11^{\prime} 11^{\prime \prime}$ ). 


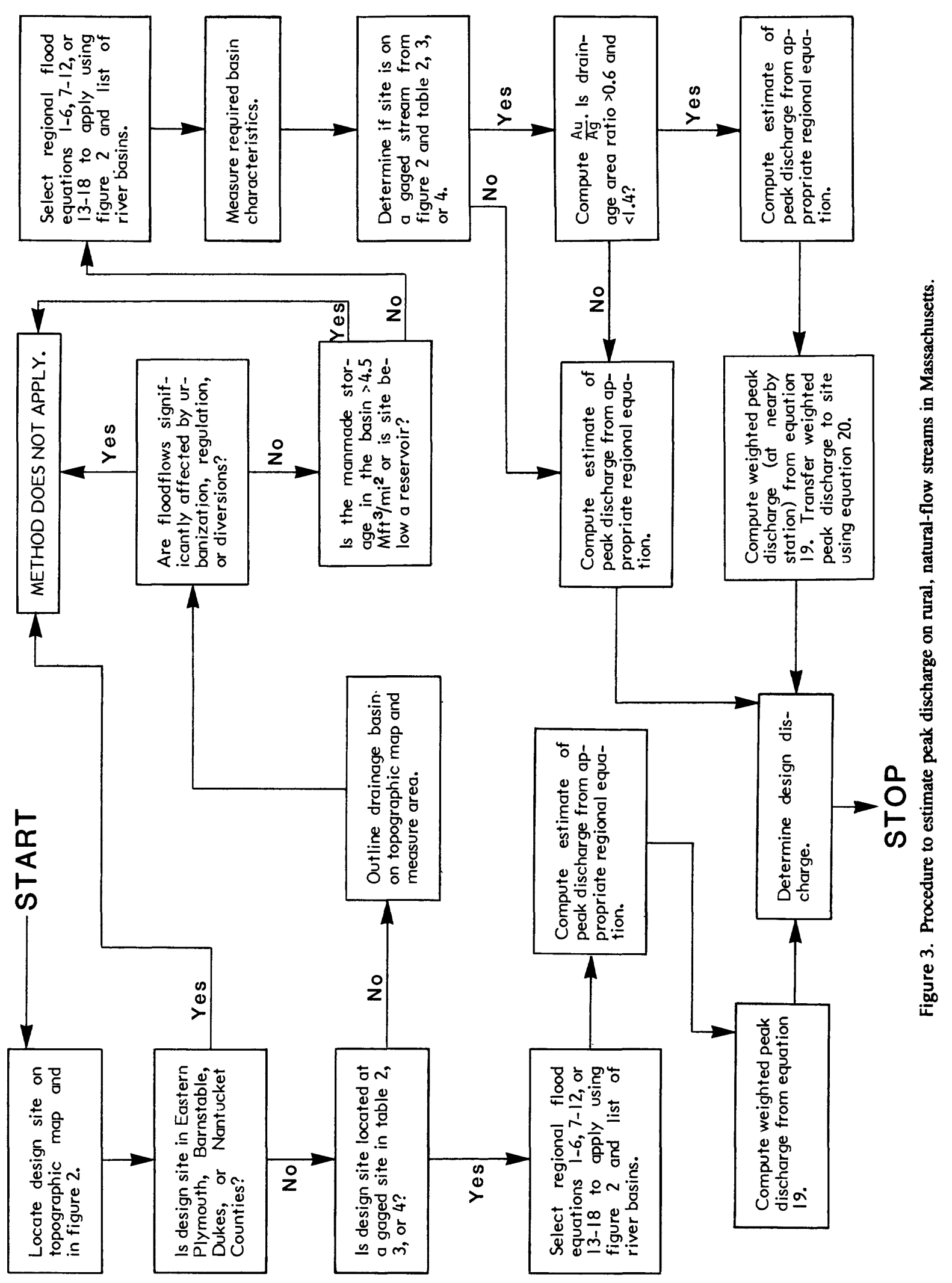




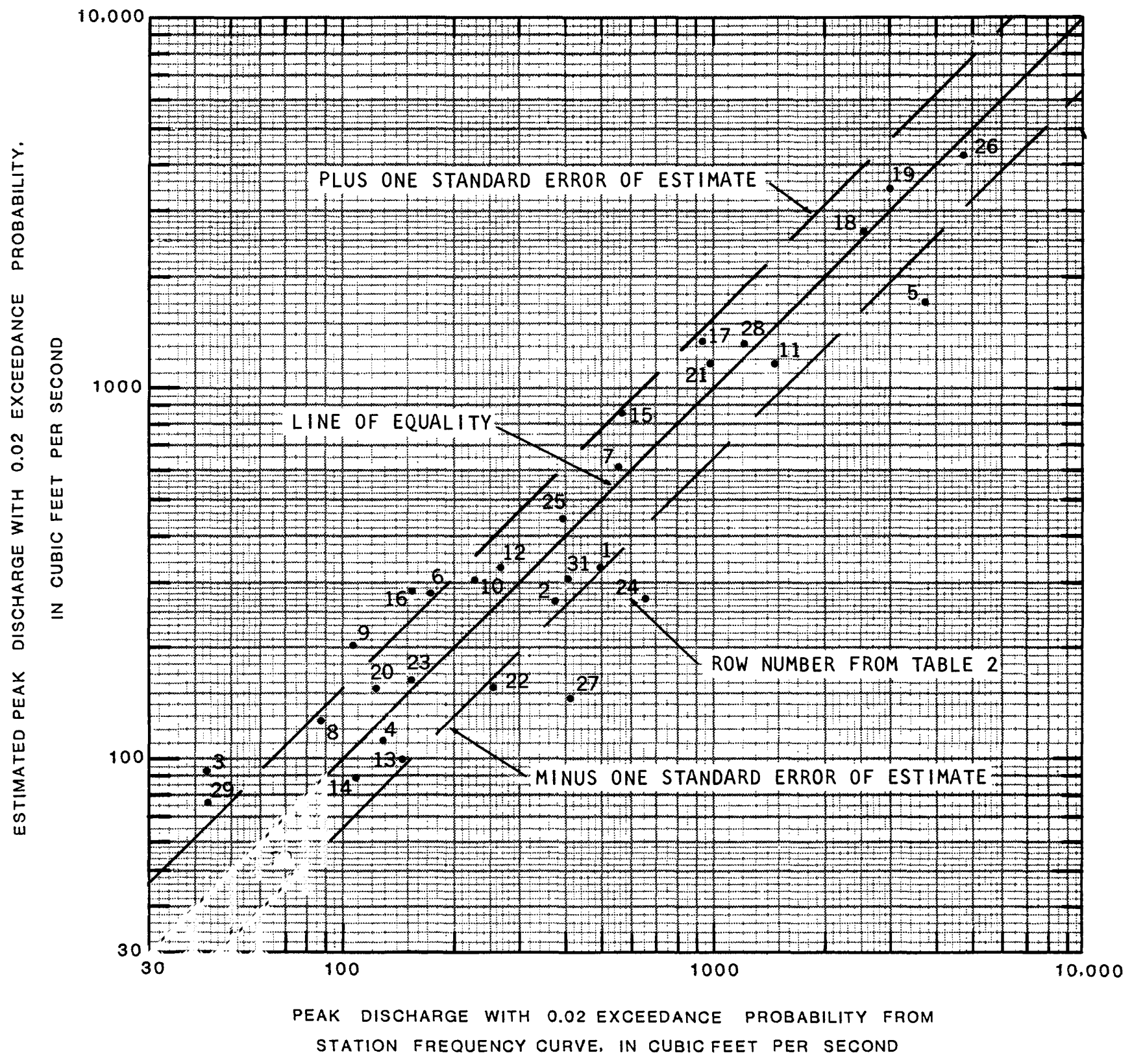

Figure 4. Observed and estimated peak discharges in the Eastern region.

After consulting figure 2, table 3, and U.S. Geological Survey (1975), it was found that this site is in the Central region at a crest-stage partial-record station, station number 01173330 , operated from 1964 to 1974.

Determine the regression flood discharge from equation 11.

Basin parameters from table 3 are as follows:

$$
\begin{aligned}
& \text { Area }(A)=1.01 \mathrm{mi}^{2} \\
& \text { Storage index }(S t)=0.0+0.5=0.5 \\
& Q_{0.02}=141.9 A^{0.785} S t^{-0.217} \\
& Q_{0.02}=141.9(1.01)^{0.785}(0.5)^{-0.217}=166 \mathrm{ft}^{3} / \mathrm{s}
\end{aligned}
$$

Station value for this flood peak from table 3 is $155 \mathrm{ft}^{3} / \mathrm{s}$.
The weighted discharge is computed using equation 19:

$$
Q_{t(w)}=\frac{\left(Q_{t(s)} \times N\right)+\left(Q_{t(r)} \times E\right)}{N+E}
$$

where

$$
\begin{aligned}
& N=11 \\
& E=11 \text { from table } 5
\end{aligned}
$$

$$
Q_{0.02(\mathrm{w})}=\frac{(155 \times 11)+(166 \times 11)}{11+11}=161 \mathrm{ft} / \mathrm{s}
$$




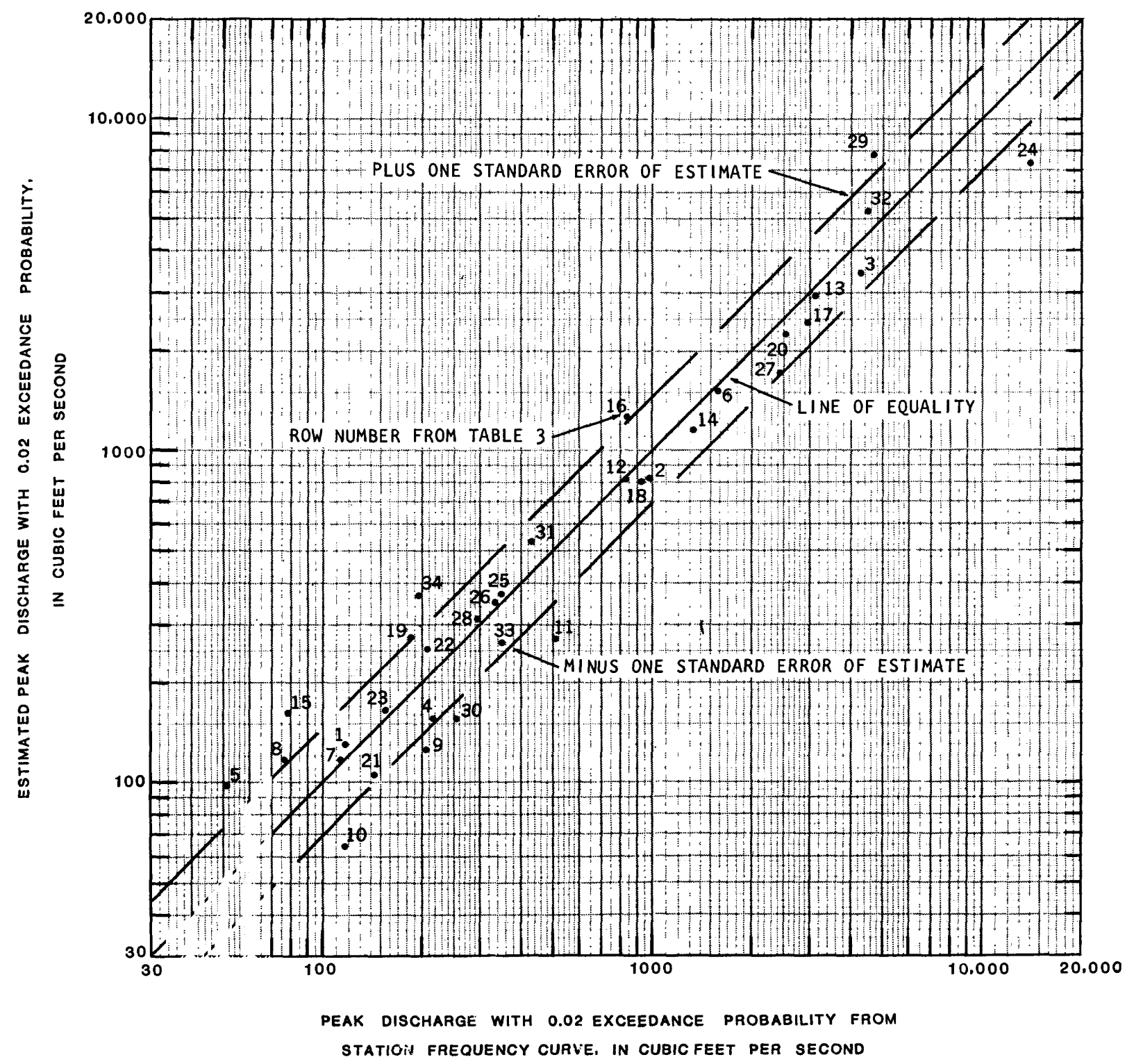

Figure 5. Observed and estimated peak discharges in the Central region.

\section{Site on Gaged Stream}

Suppose, for the sake of illustration, that an estimate of the peak discharge is required on Fish Brook in Gilbertville.

Given: Drainage area $(A)=0.75 \mathrm{mi}^{2}$

$$
\text { Storage index }=0.0+0.5=0.5
$$

Compute the 0.02 exceedance probability flood.

Because we are aware that this site is on a gaged stream, the drainage area ratio of the gaged and ungaged site is first computed:

$$
\frac{A_{u}}{A_{g}}=\frac{0.75}{1.01}=0.74
$$

This ratio is within the required limits of 0.6 and 1.4 , and the weighted station discharge, computed in the previous example, may be transferred to the ungaged site using equation 20 .

$$
Q_{t(u)}=\left(\frac{\mathbf{A}_{u}}{\mathbf{A}_{\mathrm{g}}}\right) \times Q_{t(\mathrm{~g})}
$$

$\mathrm{x}=\mathbf{0 . 7 5}$ for the Central region

$$
Q_{0.02(\omega)}=\left(\frac{0.75}{1.01}\right)^{0.75}(161)=128 \mathrm{ft}^{3} / \mathrm{s}
$$




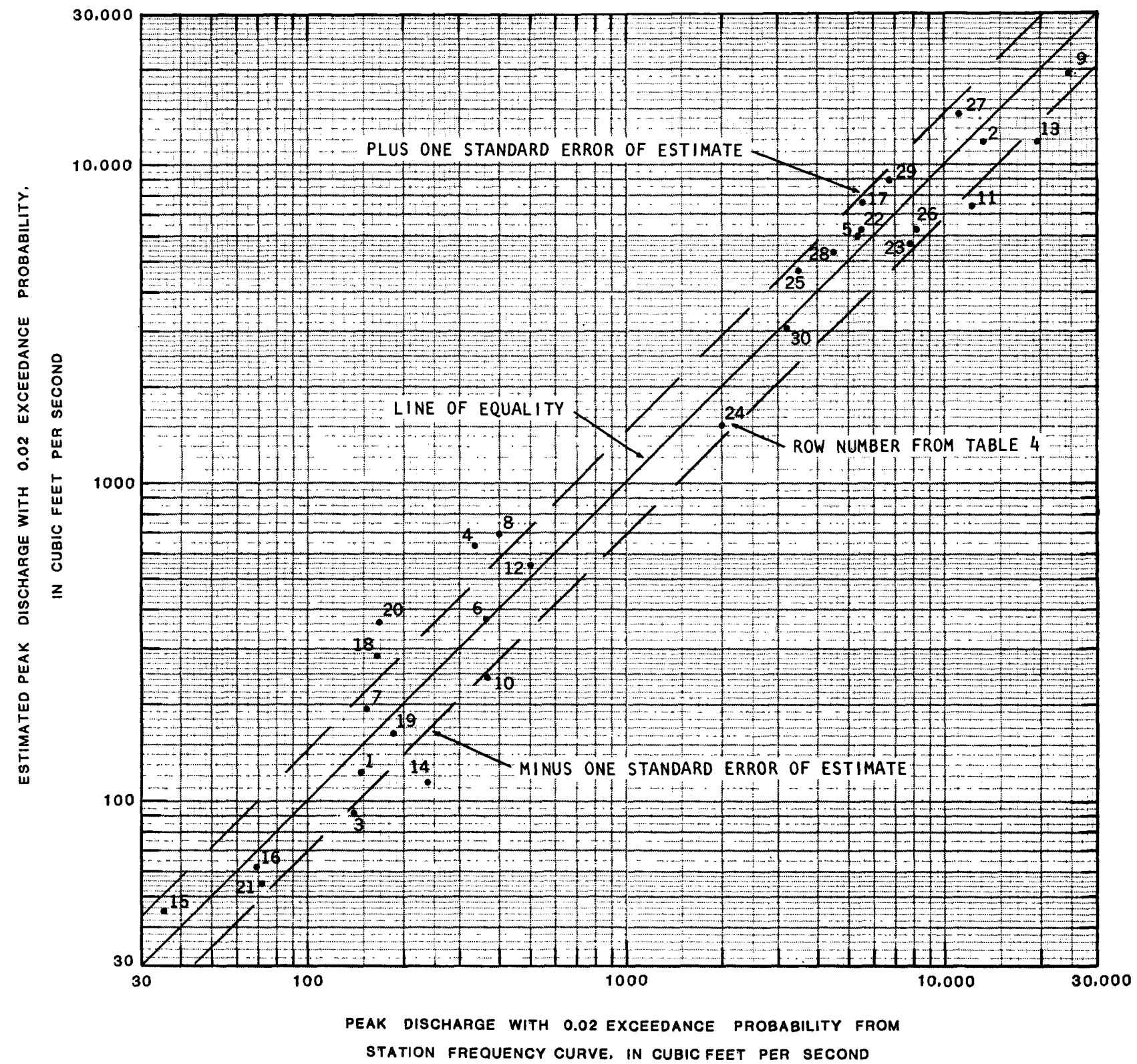

Figure 6. Observed and estimated peak discharges in the Western region.

\section{RAINFALL-RUNOFF MODEL DESCRIPTION}

Rather than awaiting the availability of long-term flood peak data on small streams, the rainfall-runoff process is modeled based upon a short period of observed storm data and daily climatic data. A series of flood peaks are generated using unit rainfall data from a long-term station.

The U.S. Geological Survey rainfall-runoff model was first developed in the late 1960's by Dawdy and others (1972) to predict flood volumes and peak rates of runoff from small, rural drainage basins using point rainfall data and daily potential evapotranspiration. Modifications to the computer program for this basic model include internal optimization of model parameters and changes in the flow routing procedure. The program for calibration of the rainfall-runoff model for a rural basin is described by Carrigan (1973). The computer programs and associated data files of the U.S. Geological Survey related to modeling the rainfall-runoff process on small streams are documented by Carrigan and others (1977). Those interested in a detailed explanation of the rainfall-runoff model and the data files are referred to these reports.

The model uses digital computer solutions of mathematical relations to approximate the hydrologic processes of infiltration, soil-moisture storage, and surfacerunoff routing. A set of 10 parameters is determined from 


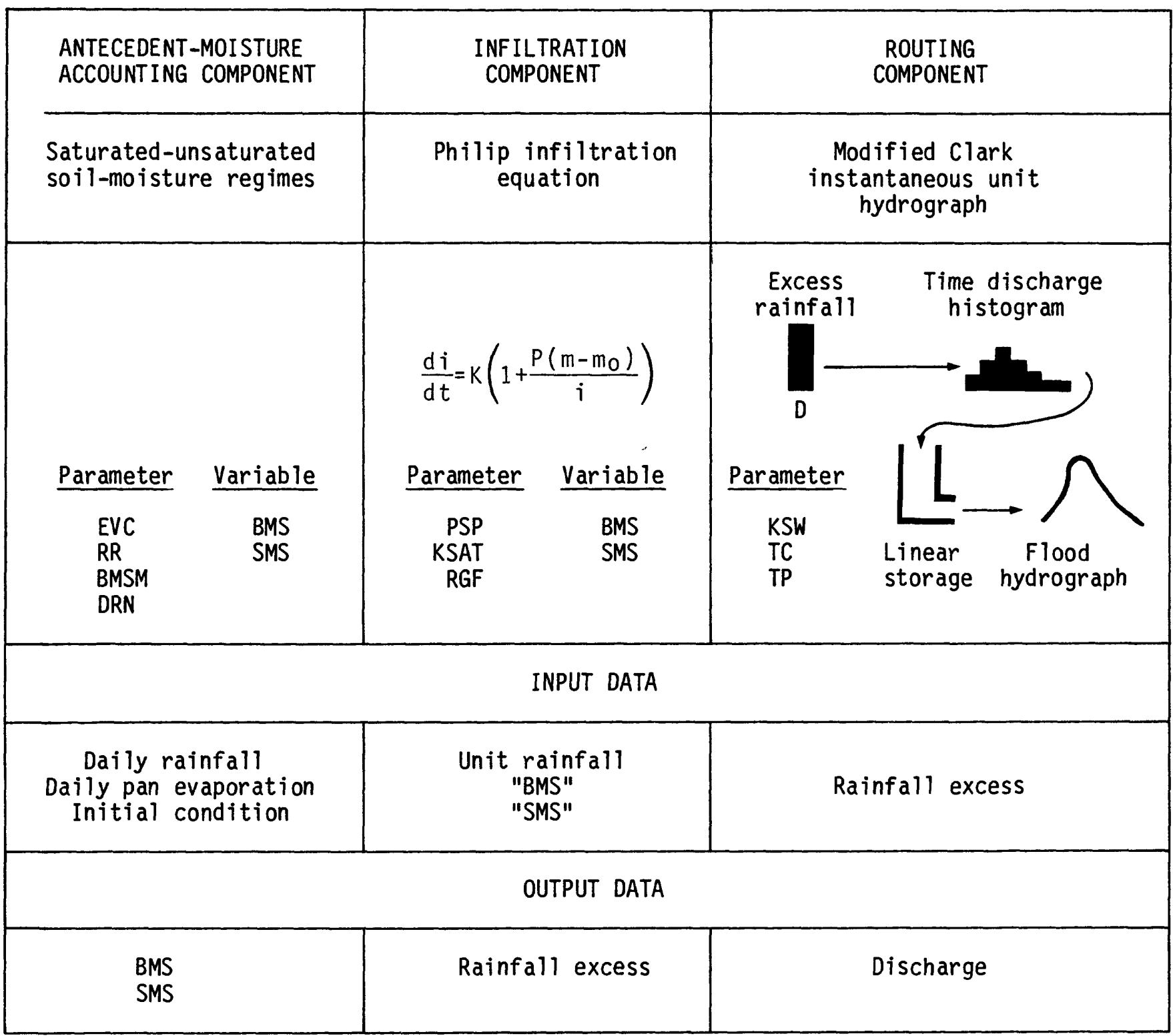

Figure 7. Schematic outline of the rainfall-runoff model with components and parameters (after Dawdy and others, 1972).

analyses of concurrent data on unit and daily rainfall, unit discharge, and daily evaporation to calibrate the model to a specific drainage basin. A schematic outline of the model is given in figure 7 , and a description of the model parameters is given in table 7 .

Daily rainfall and daily pan evaporation are used in the antecedent-moisture component (parameters EVC, $R R, B M S M$, and DRN) to determine the initial infiltration rate for a storm. The output is the amount of BMS (basemoisture storage) and of infiltrated SMS (surface-moisture storage). Unit or storm rainfall, BMS, and SMS are input for the infiltration component (parameters PSP, RGF, and KSAT) where the amount of unit rainfall that infiltrates the soil is determined and rainfall excess is produced. In the routing component (parameters $\mathrm{KSW}, \mathrm{TC}$, and TP), the rainfall excess is first converted into a translation hydrograph representative of varying travel times in the basin. Next, this translated volume is attenuated by routing through a linear function to form the outflow hydrograph.

Calibration of the model for a basin involves the optimization of the 10 parameters given in table 7. A trialand-error hill-climbing type of parameter adjustment technique, based upon a method devised by Rosenbrock (1960), searches for the minimum value of an objective function. This function is the sum of the squared deviations of the logarithms of observed peak flows from computed peak flows, or of the storm runoff, or a combination of peaks and runoff. The initial value of the 10 parameters is estimated and the range of values each parameter can 
Table 7. The 10 rainfall-runoff model parameters and their application in the modeling process

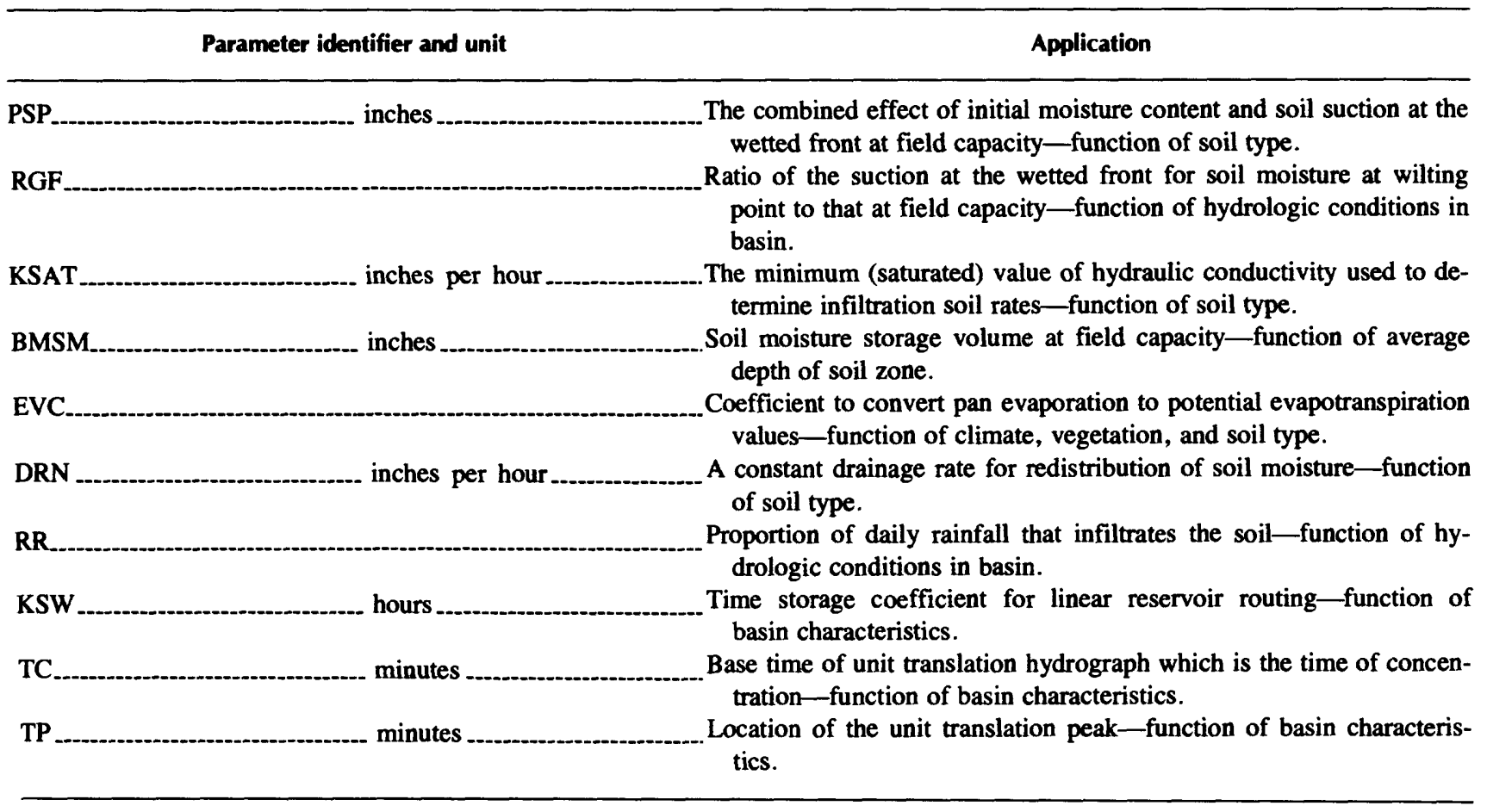

assume is set. With the observed rainfall and evaporation data as input, the model generates a synthetic set of flood hydrographs that are compared with the observed set of hydrographs, adjusts a parameter value, and repeats this process until the comparison between synthesized record and observed record cannot be improved.

This optimization process is repeated during three phases of the modeling process. In phase 1 , the parameters controlling the volume of runoff (PSP, KSAT, DRN, RGF, BMSM, EVC, and RR) are adjusted to minimize the differences in observed and computed runoff. Hydrograph shape parameters are held constant during this initial phase. The optimization process is reversed in phase 2 ; the routing parameters (TP, TC, and $\mathrm{KSW}$ ) are allowed to seek their optimum values while the runoff parameters are fixed at their previously determined values. The simulated peak flows, adjusted by the ratio of observed runoff to simulated runoff, are compared in the objective function. This adjustment to the peak flows is made to minimize errors in rainfall data and in the moisture-accounting and infiltration parameters. In phase 3, the parameters controlling the shape of the synthetic hydrograph are fixed, while the runoff volume parameters are adjusted until the best comparison of observed and simulated peak flows is obtained.

With the evaluation of the 10 parameters for a specific drainage basin by this optimization technique, a long-term record of daily rainfall and pan evaporation and unit rainfall during significant storms are used to generate a series of flood events.
Important assumptions necessary to calibrate and to use the rainfall-runoff model include the following:

1. Rainfall is uniformly distributed over the basin.

2. Runoff is not affected by snowmelt, and winter storms are insignificant compared to summer storms.

3. Long-term rainfall and evaporation records are representative of the climatic conditions in the small basins.

4. Relationship between the factors affecting the rainfall and runoff in the basins remains constant during the calibration period.

The calibration of the model was limited to basins less than $8 \mathrm{mi}^{2}$ to reduce the areal variability of rainfall and the screening process to select storms for calibration eliminated any unusual events. Only summer-type storms were used to calibrate the model. The resulting synthetic frequency curves were adjusted as discussed in the section on flood-frequency curves.

\section{Data Collection}

The 10 stream-gaging stations established to define the flow characteristics of small streams were also instrumented with recording rain gages in order to collect concurrent rainfall and discharge data. Unit rainfall and unit stage data were collected from the spring of 1963 to September 1974 at 15-minute intervals and stored in a 16channel paper tape format. During the winter months only the stage record was maintained. A single timer activated the punch cycle for both the stage and rain recorders. 
The rainfall recorders proved difficult to operate during the winter months. Accumulated water in the collecting cylinders froze, even with the addition of an antifreeze agent. In the western part of the State, the rain gages were operated, generally, from April through at least November. The rain recorders in eastern Massachusetts were continued in operation during as much of the winter period as possible because a continuous record of daily rainfall is required for modeling.

Daily precipitation data were obtained from the $\mathrm{Na}$ tional Weather Service station at Boston, Mass., for the period 1931 to 1976 . This was the only available longterm station in the State or surrounding area with recording rain gage records to allow the reduction to unit data. Daily pan-evaporation data from the National Weather Service station at Rochester, Mass., were used in all the calibrations. The statewide average evaporation is approximated by this location according to maps in Knox and Nordenson (1955), and U.S. Weather Bureau (1959c). This was the only station in the area with a long period of record-1952 to 1973 .

\section{Data Analysis}

The rainfall digital tapes were machine translated to magnetic tape for computer processing and storage of the unit and daily data. Daily rainfall records at each of the 10 stations were edited for periods of faulty record especially during the winter months. Monthly and daily rainfall totals were compared with those for a nearby National Weather Service station. The data for the missing winter months and periods of faulty or no record were estimated from the weather station used to screen the data. A complete record of daily precipitation was stored on file for each of the 10 recording stations during the period October 1963 to September 1974.

The observed storm events to calibrate the rainfallrunoff model to each of the 10 river basins were selected by using the published records of daily mean discharge and daily precipitation. These storm events were chosen to represent a range in storm magnitudes on the basis of the following criteria: antecedent conditions, observed peak discharge magnitudes, rainfall intensity, and resulting discharge hydrograph. Stage digital tapes covering the storm periods were reprocessed to magnetic tape to obtain the discharge hydrograph at 15 -minute intervals produced by the storm rainfall. Prior to processing these records, the computational procedures to analyze the daily mean discharge records at each station were reviewed for the 1963 to 1974 water years. The applicable rating curve with any datum and (or) shift adjustments was used to convert the recorded gage heights to discharges. After computer storage of the unit-rainfall and discharge data, the storm periods were edited to insure that the data were complete and representative of uniform rainfall over the basin.

About 20 to 30 storm events per site, except for the Marsh Brook at Lenox station, were initially selected for the calibration process. The available storm data for this station proved insufficient to model this basin. The 10 storm events remaining, after removing those unrepresentative of uniform rainfall and runoff over the Marsh Brook basin, were insufficient to define the rainfall/runoff relation. A time interval of 15 minutes did not define the rapid response of the discharge hydrograph and the medium-to-high end of the stage discharge relationship was questionable at this site.

An inspection of land use in the Dorchester Brook at Brockton basin indicated a significant increase in the degree of urbanization during data collection. Several storm events occurred during winter months. The Dorchester Brook basin was omitted from the final calibration process because a sufficient number of homogeneous storm events could not be defined.

Selecting long-term rainfall events to later simulate historic peak discharges at the eight remaining stations was based upon an analysis of daily precipitation at Boston from October 1930 to September 1976. Five storms per water year (maximum) were chosen as those storm events most likely to have produced the annual peak discharge. The selection criteria were storms with a 2-day sum equal to or greater than 1 inch and with a 1-day maximum total in the top five storms for the year. This technique was proved succussful by R. W. Lichty (oral commun.) in identifying the storm producing the annual peak discharge. A 1-inch threshold was chosen to provide a suitable array of events after inspecting the rainfall-frequency curve for Boston in U.S. Weather Bureau (1955). For the selected storm events, the Boston daily rainfall was reduced to 5 -minute unit rainfall by the National Climatic Center in Asheville, N.C., from the original charts.

Evaporation records for the months of December through April were estimated on the basis of monthly data for Chestnut Hill Reservoir from 1875 to 1890 (Myer, 1928 , p. 225). The continuous evaporation data for 1952 73 were used to generate synthetic daily evaporation data to complete the period 1931-76. In this synthesis program, a harmonic function was fitted by least squares to the observed daily data.

\section{ANALYTICAL TECHNIQUES \\ Calibration of the Rainfall-Runoff Model}

Initial magnitudes of parameters PSP, RGF, KSAT, BMSM, EVC, RR, KSW, and TC were estimated on the basis of soil, land-use and topographic maps, hydrograph shape, and climatic maps. Upper and lower boundary values were selected to allow each parameter to fluctuate within a reasonable range of occurrence. Based upon experience gained by others in use of the model as part of the nationwide small streams flood-frequency studies, the drainage rate parameter DRN was fixed at 1.0 and the routing parameter TP was fixed at $0.5 \mathrm{TC}$. 
Because the model simulates only direct storm runoff, the observed discharges were adjusted for the flow already available, that is, for dry-weather or base flow. The calibration program computes for each storm the direct runoff volume and peak discharge given the base flow value and the starting and ending times for rainfall and runoff determination. A mean base flow value was estimated for each storm event from a sketch of the base flow hydrograph on each observed discharge hydrograph. A mean base flow value was adequate for each storm because base flow separation techniques are not exact. Base flow values for these small basins were generally a small percentage of the respective peak discharges.

The summer-type storms for possible use in model calibration represented a range in peak flows, rainfall intensity, and antecedent conditions. All the storms were included in the initial phase 1 and phase 2 calibration runs. The storms were then screened by comparing the recorded rainfall with the simulated and observed hydrographs to eliminate those storms with unrepresentative rainfall or runoff. The base flow estimation was reviewed and storms were omitted from further analysis if the base flow separation appeared questionable as in storms with a long recession.

The phase 1 and phase 2 calibrations were repeated as necessary on a reduced set of storms. The pan evaporation coefficient EVC and the daily rainfall infiltration parameter $\mathbf{R R}$ were fixed from information in these runs. Phase 3 computations were run on a reduced set of storms to determine the final set of optimum parameter values. The observed and synthetic flood peaks were statistically tested for significance in the relationship and for bias in the results. If necessary, remaining outliers were removed from the phase 3 calibration to eliminate any bias. The modeling results were significant at all of the eight stations, and the results were unbiased at all the stations except for Bassett Brook near Northampton. This bias was caused largely by the relatively small range in the available peak discharges to calibrate the model to the Bassett Brook basin. The final group of optimum parameter values for the eight modeled sites is given in table 8 .

\section{Peak Discharge Synthesis and Frequency}

Long-term records of peak discharges were simulated for each of the eight modeled basins. The optimized model parameters, long-term unit and daily precipitation at Boston, and long-term (both synthesized and observed) daily pan-evaporation data at Rochester were used as input. Logarithms of annual maximum simulated discharges from 1931 to 1976 were fitted to a Pearson Type III distribution to provide a long-term synthetic flood-frequency curve. Bias in the synthetic frequency curve was corrected with the value of the correlation coefficient between observed and calibrated peak discharges. The adjusted discharges were generally within 10 percent of the unadjusted figures.
Resulting synthetic frequency curves only define peak frequency during nonsnowmelt or summer months because the 10 optimized parameters represent summer runoff conditions. This rainfall-runoff model does not account for the factors influencing winter runoff, and there is insufficient data to model the winter storms. The annual flood-frequency curve was computed from a combination of the synthetic (summer) and winter curve.

A winter frequency curve was developed for the eight modeled basins from the peak discharges for each winter period, November to April, during the data-collection period. The observed winter frequency curve was multiplied by the ratio of the winter frequency curves, for a nearby long-term station to adjust the observed curve to long-term conditions. These winter frequency curves were defined using the period of record for both the modeled basin and the long-term station.

The annual long-term flood-frequency curves for the eight calibrated stations were computed by combining the summer or synthesized curve with the winter frequency curve.

The frequency curves for the summer and winter months are combined using the equation:

where

$$
P_{a}=P_{w}+P_{s}-\left(P_{w} P_{s}\right)
$$

$P_{a}$ is the probability of exceedance on an annual basis,

$P_{w}$ is the probability of exceedance from the winter curve, and

$P_{s}$ is the probability of exceedance from the summer curve.

For selected discharges, the probability of exceedance is determined from the winter and summer curves and entered in equation 21 to compute the annual probability for the selected discharges. A summary of the annual, winter, summer, and combined flood-frequency relations is given in table 9. These curves are shown in figure 8 for Walker Brook near Becket Center. Peak discharges for exceedance probabilities $0.5,0.2,0.1,0.04,0.02$, and 0.01 were determined from the final composite frequency curve for use in the regression analysis.

\section{Station Floodflow Frequency}

A flood-frequency curve relates annual flood peak magnitude to probability of occurrence. Probability of occurrence or exceedance probability is the percent chance of a given flood event being exceeded in any one year. Recurrence interval, the reciprocal of probability of occurrence times 100 , is the average number of years between exceedances over a long period of time.

Station flood-peak frequency curves were computed for stations with at least 10 years of natural-flow record using the latest procedures recommended by the U.S. Water Resources Council (1977). Base 10 logarithms of observed annual peak discharges were fitted to a Pearson Type III distribution by using a weighted skew coefficient 


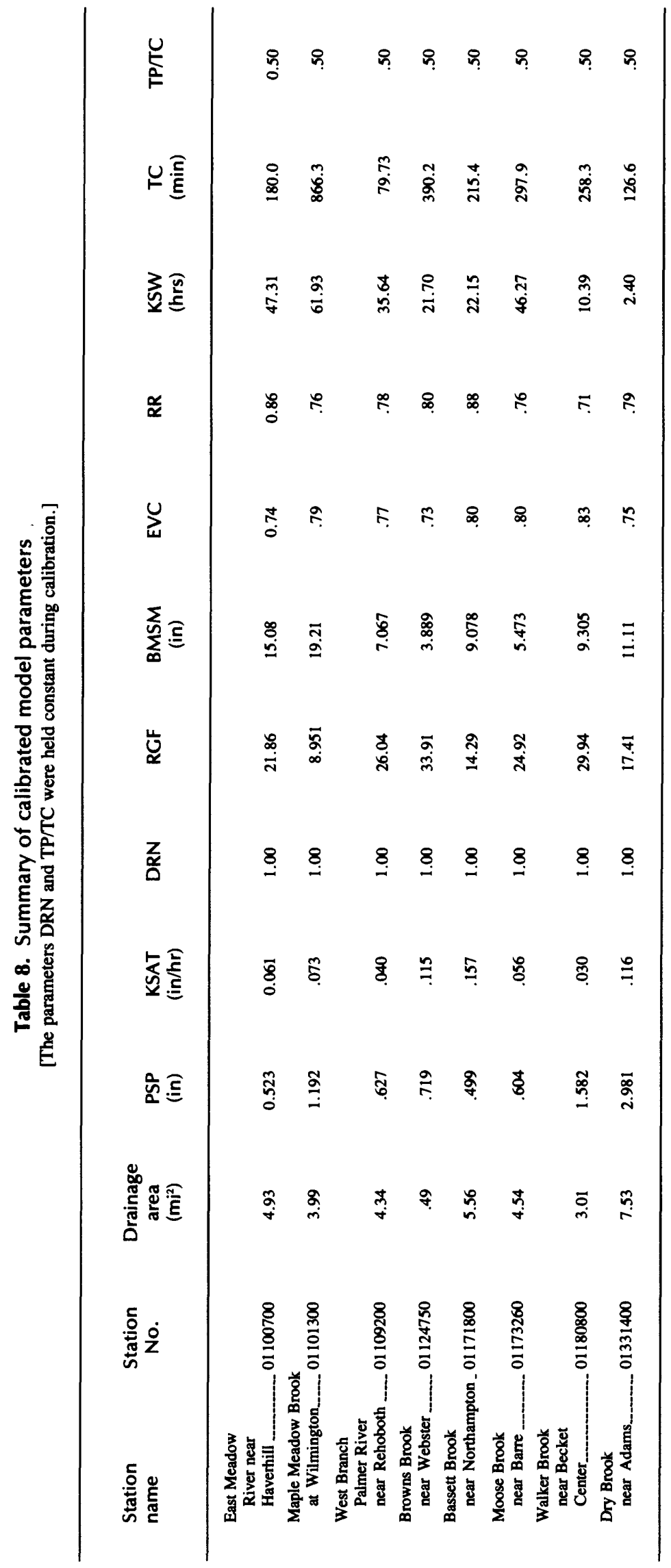




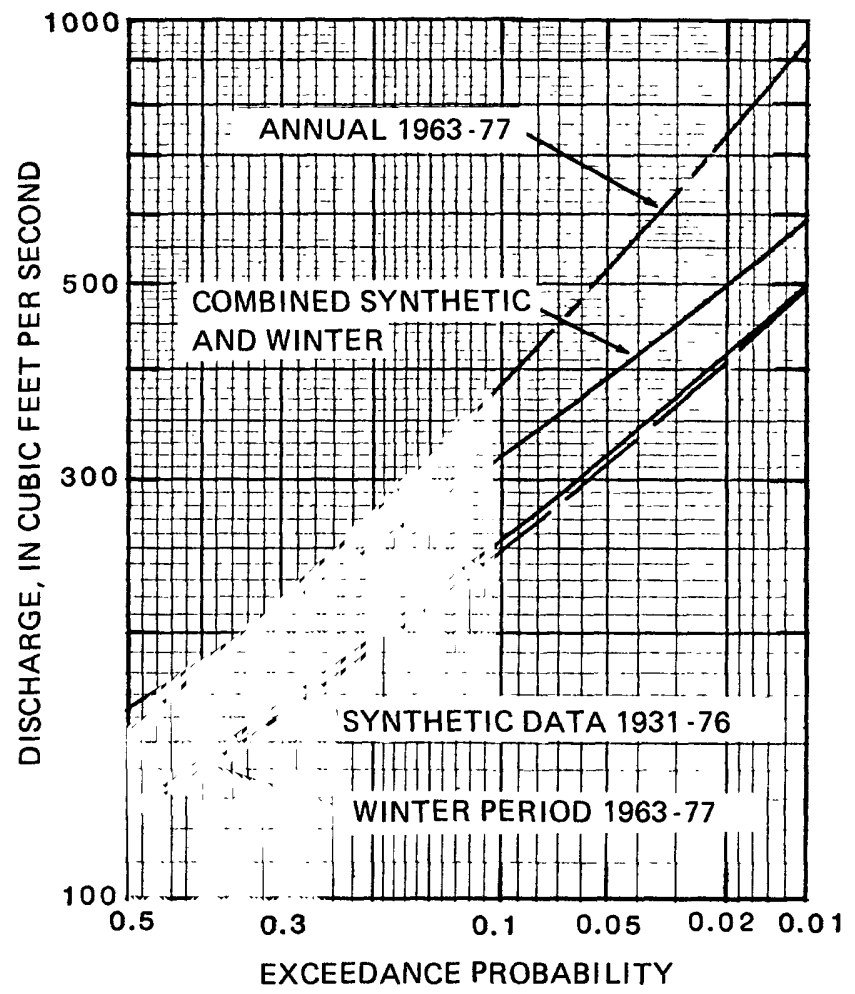

Figure 8. Flood-frequency curves for Walker Brook near Becket Center, Mass.

and adjusting for historic flood data, high outliers, and low outliers. The discharge $Q$ at selected exceedance probabilities of $0.5,0.2,0.1,0.04,0.02$, and 0.01 was computed by the equation:

$$
\log Q=\bar{x}+K S
$$

where

$\bar{x}$ is the mean of the logarithms,

$S$ is the standard deviation of the logarithms, and

$K$ is a factor that is a function of the skew coeffi-

cient and exceedance probability.

Information on historical floods and high outliers was taken from the annual streamflow data reports (U.S. Geological Survey, 1975). Unpublished station summaries by W. B. Gannon and M. T. Thomson for the report "Historical Floods in New England" (Thomson and others, 1964) were helpful in assigning a historic period to the high outliers.

For stations with records of less than 25 years, the skew coefficient was taken from the generalized skew map (U.S. Water Resources Council, 1977) or from figure 1. For stations with records longer than 25 years, the station skew was weighted with the generalized skew value.

Flood-frequency curves for eight small watershed stations with synthetic peak data were weighted as discussed in the section "Peak Discharge Synthesis and Frequency." The combined frequency curve for Bassett Brook compared favorably with an adjacent long-term sta- tion and was used in the frequency analysis. The observed annual peaks were used to compute the curve for Marsh Brook at Lenox because there was an insufficient number of storm events available to calibrate the rainfall-runoff model to this site. The record for Dorchester Brook was not used in the frequency analysis because it represented changing land-use conditions in the basin.

The log-Pearson Type III frequency analyses were computed through the National Water Data Storage and Retrieval System (WATSTORE) utilizing the U.S. Geological Survey's peak flow data file with computer program J407 (Kirby, 1979). These analyses were reviewed for goodness of fit of the observed data. A more detailed discussion of the flood-frequency analysis is given in U.S. Water Resources Council (1977).

Estimates of the observed peak discharges used in the regression analysis at the $0.5,0.2,0.1,0.04,0.02$, and 0.01 exceedance probabilities are given for each station in tables 2, 3, and 4. An improved estimate of floodflows at these stations is obtained by weighting the regression equation estimate with the station value. This technique is explained in the section "Summary of Estimating Techniques-Gaged Sites."

\section{Regional Regression Analysis}

There is a need for information on the magnitude and frequency of floods for sites without a systematic record of peak flows. Equations relating floodflow at gaged sites to easily measured basin and climatic characteristics fulfill this need to estimate floodflows at ungaged sites. Rather than relying on a single nearby site to transfer the flood information, a regional regression analysis utilizes the floodflow experienced in a region to develop the estimating relations. The influence of an individual floodfrequency relation that may be biased because of time sampling or because of weather patterns is minimized.

Previous flood studies (Kinnison and Colby, 1944, and Benson, 1962) had determined the importance of physical and climatic characteristics of a drainage basin in estimating flood peaks. The more important factors influencing floodflows were chosen after a review of the 1977 regression analysis. These basin characteristics are useful because they can be readily measured on topographic or climatic maps. The nine basin indices initially tested in the regression analysis were drainage area, mainchannel slope, main-channel length, area of lakes, ponds, and swamps, mean basin elevation, forested area, mean annual precipitation, precipitation intensity for 24 hours at a 2-year recurrence interval, and mean minimum January temperature. The basin storage index was improved for this analysis by including the area of swamps together with the area of lakes and ponds.

This multiple-regression analysis indicated that the statewide variation in floodflows can best be accounted for by separating the State into three regions-Eastern, 
Central, and Western. Floodflows in these regions of Massachusetts are best defined by a combination of indices for drainage area, slope, elevation, and storage.

\section{Data Network}

Flood-frequency data for both large streams and small streams were analyzed together in the regression analysis in order to strengthen the discharge area relationship and to use the wealth of flood experiences on the larger streams, thus minimizing the time-sampling error.

Gaging stations and crest-stage partial-record stations with at least 10 years of natural-flow record collected through 1975 were used as the data base for the flood-frequency regression analysis. The annual peaks were omitted from the frequency analysis for a station if reservoir construction increased the usable storage in the basin over $4.5 \mathrm{M} \mathrm{ft}^{3} / \mathrm{mi}^{2}$ or if the peak flow was considered significantly affected by regulation or diversion (Johnson, 1970). Peak-flow records were excluded from the data base if major changes occurred in the factors affecting the flow regime in the river basin, such as the degree of urbanization or construction of reservoirs, throughout the period of peak-flow record. Station records representing relatively constant conditions in the basin were used in the frequency analysis. Stations where the high end of the stage-discharge relationship was not well defined were omitted from this analysis.

Fifty-one continuous-record stations and forty-four crest-stage partial-record stations located in Massachusetts and in adjacent areas of Connecticut, New Hampshire, New York, Rhode Island, and Vermont (fig. 2) were used as the data base for the analysis in this report. Basin and flood characteristics for each of these sites are given in tables 2,3 , and 4 .

\section{Multiple-Regression Analysis}

A linear regression model of the form $\log Q=$ $\log a+b \log A+c \log B+d \log C \ldots y \log Z$ (23) where, $Q$ is the flood peak, $A, B$ to $Z$ are basin parameters, $a$ is the regression constant, and $b, c$, to $y$ are regression coefficients, was selected as the basic estimating relation. Earlier flood studies have shown that a linear relationship exists between the logarithms of the dependent streamflow variable and of the basin and climatic parameters. Thus, all variables were transformed to logarithms for the regression analysis. Prior to transformation, a constant of 0.5 was added to each storage index to avoid computing the logarithm of zero which is undefined. Also, the January mean minimum temperature was subtracted from 32 to represent the number of degrees below freezing. This index was found significant by Benson in his study of factors influencing flooding in New England (Benson, 1962).
Standard multiple-regression techniques were used to define the relationship between flood peaks (dependent variable) at selected exceedance probabilities to a suite of basin and climatic indices (independent variables). Computer programs for step-forward and step-backward methods were used (Draper and Smith, 1967). Those independent variables that had a 95 percent probability of effectiveness were retained in the regression equation. That is, the regression coefficient of the independent variable is significantly different from zero at the 5 percent confidence level.

Initially, the flood-peak variation was tested in the eastern and western Massachusetts regions defined in the 1977 analysis. Basin characteristics for length and elevation were eliminated as independent variables because these parameters were highly correlated with slope and temperature parameters, respectively. The inclusion of highly related independent variables will mask the real influence of the other independent variables and affect the various tests of significance of the independent variables. Slope was retained because it is an important variable in estimating natural flows as indicated by the use of a slope factor in the open-channel flow equations. Elevation, a time consuming parameter, was deleted rather than temperature because mean basin elevation is also correlated with the precipitation indices in the Eastern region.

Standard errors of estimate for the Eastern and Western regional equations were slightly higher than those for 1977. Longitude was a significant variable, in addition to area, slope, and precipitation, to explain the floodflow variations in the Western region. With the available data base, dividing the State into a third flood-frequency region offered the greatest potential to define this additional variability.

An analysis of the flood-frequency regions in Green (1964, pl. 1), the cumulative storm rainfall map representing the major floods of $1927,1936,1938$, and 1955 in Benson (1962, fig. 7), and climatic and elevation characteristics, indicated a third flood-frequency region was practical. Massachusetts is characterized by two distinct physiographic areas, the New England Upland and the Seaboard Lowland (Fenneman, 1938). The New England Upland (Western Massachusetts) can be further divided because of differing physical and climatic characteristics. Southwestern Massachusetts received the heaviest storm precipitation in the major floods from 1927 to 1955 (Benson, 1962, fig. 7). Land slopes and elevations west of the Connecticut River are greater than those along the east side of the Connecticut Valley (Benson, 1962, fig. 8). Regional boundaries along the Connecticut River and the coastal river basins create three regions with similar floodfrequency characteristics.

On the basis of storm precipitation, changes in relief, variations in mean annual precipitation, and hydro- 
logic areas, the State was divided into three flood-frequency regions-the river basins west of the Connecticut River (Western region), the Connecticut River basin east of the Connecticut River including the Blackstone and Quinebaug River basins (Central region), and the remaining coastal river basins (Eastern region). For consistent application of the flood equations, the regional flood boundaries were adjusted to coincide with the major drainage basin divides. The major river basins in each region are listed with the regional flood equations 1-18.

The correlation between basin and climatic characteristics was reviewed prior to multiple-regression analyses of 31, 34, and 30 sites in the Eastern, Central, and Western regions, respectively. Length was omitted because it is highly related to slope in all regions. Temperature, which is related to elevation, was not retained at this time because elevation is an important parameter in representing the regional climatic and flood variations. An elevation factor is an improved indicator of the basin-tobasin variability, rather than a generalized temperature map. In the Central region, precipitation intensity, which is related to elevation, was deleted as a variable. Including slope as an independent variable in the Central region is questionable because slope and area have a correlation coefficient of 0.8 .

Regression equations were tested both with and without slope, and the regression coefficients were examined for stability. The set of regression equations with slope contained unstable coefficients for the significant variables of area, slope, and storage. This indicated that slope should be removed as an independent variable in the Central region. Slope and area are not highly related in the other two regions.

The results of the multiple-regression analysis with a reduced set of independent variables are given in table 10. For the final estimating relations in the Eastern and Western regions, the regression equations 25-27 and 37 were re-run with independent variables $A$; and $A, S l$, and $E$, respectively, so that all equations would contain common variables. The resulting equations $1-3$ and 13 for design purposes show a slightly higher standard error of estimate $(49,45$, and 44 percent, respectively) than equations 25-27 and 37 computed by using all the significant variables. The increase in user convenience and the need to keep a group of equations consistent were felt to outweigh the slightly higher standard error.

Residual errors (differences between observed and computed values) were plotted on maps to examine for possible areal bias in the estimating relations. These plots showed no significant regional trends. The residual plots for the Eastern and Central regions were improved when stations in the Blackstone and Quinebaug River basins were analyzed as part of the Central region. Plots of the residuals against drainage area indicated the applicability of the relations to both small and large streams in the data sample.

\section{DISCUSSION AND RECOMMENDATIONS}

An improved sample of flood peaks and basin characteristics, through the recognition of three flood-frequency regions and the inclusion of adjustments for high outliers in the regression analysis, reduced the standard errors of estimate over those for the 1977 relations. This analysis included the synthetic frequency curves computed after calibration of the rainfall-runoff model at eight sites. Improvement in the standard error reflects a reduction either in the model error or the time-sampling error or, most likely, a combination of both. The data and estimating relation can be analyzed to determine the relative improvement in the model or time-sampling error.

After additional flood-peak data are collected, the flood-peak estimating relations should be re-examined as well as the peak-stage network in satisfying the program objectives. During the interim, several options are available for strengthening the rainfall-runoff model assumptions or for further analytical effort.

1. Rainfall is an important parameter in estimating floodflows. The current regional division may account for the differing intensity regimes in the State. An improved rainfall index map representative of the basin-to-basin variability in rainfall intensity may provide a significant parameter to improve the flood-peak estimating relations.

2. It was necessary to use Boston long-term rainfall data as representative of the statewide rainfall distribution. This assumption should be investigated when data for an inland station are available. The synthetic annual flood discharges generated from two longterm rainfall records can then be tested for identical distribution.

3. The slope of the winter flood-frequency curve was steeper than expected in Eastern Massachusetts. The influence of winter storms on the shape of the annual frequency curves requires additional investigation.

4. Published historical flood information is generally unavailable on streams draining less than $10 \mathrm{mi}^{2}$. Additional information may be available from Community Flood Insurance Studies or from other engineering records.

5. Other basin indices should be tested in the regression analyses to account for the unexplained variability in floodflows especially in Eastern Massachusetts. A rainfall index, channel width, or a basin lag factor, such as timing of the flood peak, and indices from land-use maps, are possible characteristics. 
Table 9. Summary of flood-frequency relations for the eight modeled stations

[Peak discharges are listed in the following sequence: First line is computed from the annual peak data, second line is derived from peak discharges during the winter periods, third line is computed from the synthetic or summer peak discharges, and fourth line is computed from the combined synthetic and winter curves.]

\begin{tabular}{|c|c|c|c|c|c|c|}
\hline \multirow[t]{2}{*}{$\begin{array}{c}\text { Station } \\
\text { No. }\end{array}$} & \multicolumn{6}{|c|}{$\begin{array}{l}\text { Peak discharge, in cubic feet per second, with the } \\
\text { indicated exceedance probability }\end{array}$} \\
\hline & 0.5 & 0.2 & 0.1 & 0.04 & 0.02 & 0.01 \\
\hline \multirow[t]{4}{*}{ 1963-74 } & 79 & 139 & 194 & 284 & 370 & 474 \\
\hline & 75 & 119 & 152 & 197 & 232 & 269 \\
\hline & 89 & 126 & 154 & 195 & 228 & 265 \\
\hline & 105 & 150 & 184 & 230 & 266 & 305 \\
\hline \multirow[t]{4}{*}{ 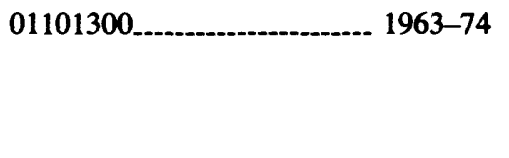 } & 50 & 78 & 101 & 138 & 171 & 209 \\
\hline & 47 & 70 & 89 & 113 & 133 & 152 \\
\hline & 47 & 70 & 88 & 113 & 134 & 157 \\
\hline & 61 & 88 & 107 & 133 & 154 & 177 \\
\hline \multirow[t]{4}{*}{ 1964-74 } & 158 & 268 & 368 & 534 & 690 & 881 \\
\hline & 139 & 203 & 251 & 312 & 360 & 406 \\
\hline & 94 & 145 & 188 & 256 & 317 & 389 \\
\hline & 155 & 225 & 278 & 349 & 404 & 469 \\
\hline \multirow[t]{4}{*}{ 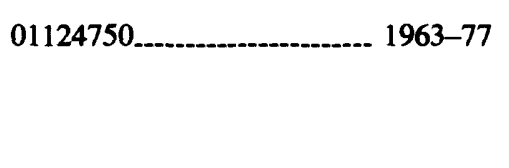 } & 15 & 33 & 54 & 94 & 140 & 203 \\
\hline & 24 & 44 & 63 & 90 & 117 & 153 \\
\hline & 11 & 18 & 23 & 29 & 35 & 41 \\
\hline & 26 & 45 & 63 & 90 & 117 & 15 \\
\hline \multirow[t]{4}{*}{ 1963-74 } & 64 & 89 & 107 & 134 & 156 & 180 \\
\hline & 56 & 72 & 83 & 96 & 105 & 114 \\
\hline & 115 & 178 & 228 & 302 & 366 & 436 \\
\hline & 116 & 178 & 228 & 302 & 366 & 436 \\
\hline \multirow[t]{4}{*}{ 1963-74 } & 79 & 138 & 191 & 279 & 361 & 462 \\
\hline & 74 & 101 & 119 & 142 & 161 & 181 \\
\hline & 72 & 104 & 130 & 167 & 199 & 235 \\
\hline & 90 & 123 & 146 & 180 & 206 & 236 \\
\hline \multirow[t]{4}{*}{ 1963-77 } & 152 & 273 & 384 & 567 & 741 & 951 \\
\hline & 124 & 198 & 256 & 343 & 418 & 500 \\
\hline & 123 & 192 & 248 & 334 & 409 & 494 \\
\hline & 163 & 252 & 319 & 415 & 498 & 594 \\
\hline \multirow[t]{4}{*}{ 01331400 1963-74 } & 505 & 664 & 778 & 930 & 1050 & 1180 \\
\hline & 350 & 547 & 704 & 936 & 1130 & 1355 \\
\hline & 367 & 705 & 1010 & 1550 & 1950 & 2485 \\
\hline & 505 & 826 & 1080 & 1550 & 2000 & 2510 \\
\hline
\end{tabular}

6. Direct data-collection and analysis efforts toward river basins not covered by the present estimating equations and to urbanized basins. Urban studies in other areas have shown that urban and suburban development significantly increases the flood peak over rural conditions. In the Washington, D.C., metropolitan area, urban development increased the flood peaks by a factor that ranges from 2 to 8 (Anderson, 1970).

\section{SELECTED REFERENCES}

Anderson, D. G., 1970, Effects of urban development on floods in northern Virginia: U.S. Geological Survey Water-Supply Paper 2001-C, 22 p.

Benson, M. A., 1962, Factors influencing the occurrence of floods in a humid region of diverse terrain: U.S. Geological Survey Water-Supply Paper 1580-B, 64 p. 
Table 10. Summary of preliminary regional estimating

relations in the form $Q_{i}=a A^{b} S l{ }^{S} S t^{d} E^{e} P^{s}(24)$

[The final equations in the section "Estimating Techniques"

contain independent variables common to each group.]

\begin{tabular}{|c|c|c|c|c|c|c|c|c|}
\hline \multirow{2}{*}{$\begin{array}{c}\text { Equa- } \\
\text { tion } \\
\text { No. }\end{array}$} & \multirow{2}{*}{$\begin{array}{c}\text { Exceed- } \\
\text { ance } \\
\text { proba- } \\
\text { bility } \\
\quad i\end{array}$} & \multirow{2}{*}{$\begin{array}{c}\text { Regression } \\
\text { constant } \\
\quad a\end{array}$} & \multicolumn{5}{|c|}{ Regression coefficients for } & \multirow{2}{*}{$\begin{array}{c}\text { Average } \\
\text { standard } \\
\text { error of } \\
\text { estimate } \\
\text { (percent) }\end{array}$} \\
\hline & & & $A$ & $s l$ & $S t$ & $E$ & $P$ & \\
\hline \multicolumn{9}{|c|}{ Eastern region } \\
\hline 25 & 0.5 & 16.2 & 0.760 & 0.221 & $\ldots$ & $\ldots$ & $\ldots$ & 44 \\
\hline 26 & .2 & 27.7 & .737 & .190 & $\ldots$ & $\ldots$ & $\ldots$ & 42 \\
\hline 27 & .1 & 38.4 & .722 & .173 & $\ldots$ & --- & --- & 42 \\
\hline 28 & .04 & 96.7 & .651 & $\ldots$ & $\ldots$ & $\ldots$ & $\ldots$ & 46 \\
\hline 29 & .02 & 118 & .645 & $\ldots$ & $\ldots$ & $\ldots$ & $\ldots$ & 48 \\
\hline 30 & .01 & 143 & .638 & $\ldots$ & $\ldots$ & $\ldots--$ & --- & 52 \\
\hline \multicolumn{9}{|c|}{ Central region } \\
\hline 31 & 0.5 & 41.1 & 0.743 & --- & -0.097 & $\ldots$ & - - & 25 \\
\hline 32 & .2 & 65.2 & .751 & $\ldots$ & -.139 & $\ldots$ & $\ldots$ & 28 \\
\hline 33 & .1 & 86.0 & .760 & -- & -.166 & $\ldots$ & -- & 30 \\
\hline 34 & .04 & 115 & .775 & $\ldots$ & -.195 & $\ldots$ & $\ldots$ & 34 \\
\hline 35 & .02 & 142 & .785 & $\ldots$ & -.217 & $\ldots$ & $\ldots$ & 38 \\
\hline 36 & .01 & 173 & .797 & $\ldots$ & -.237 & $\ldots$ & $\ldots$ & 41 \\
\hline \multicolumn{9}{|c|}{ Western region } \\
\hline 37 & 0.5 & 0.155 & 0.967 & 0.159 & --- & 0.338 & 1.63 & 26 \\
\hline 38 & .2 & 1.05 & .968 & .178 & $\ldots$ & .469 & $\ldots$ & 28 \\
\hline 39 & .1 & 1.23 & .968 & .188 & $\ldots$ & .480 & $\ldots$ & 31 \\
\hline 40 & .04 & 1.31 & .969 & .204 & $\ldots$ & .506 & $\ldots$ & 36 \\
\hline 41 & .02 & 1.41 & .970 & .214 & $\ldots$ & .520 & $\ldots$ & 40 \\
\hline 42 & .01 & 1.48 & .974 & .224 & $\ldots$ & .536 & $\ldots$ & 46 \\
\hline
\end{tabular}

Carrigan, P. H., Jr., 1973, Calibration of U.S. Geological Survey rainfall-runoff model for peak flow synthesis, natural basins: U.S. Geological Survey Computer Contribution, 114 p., available only from U.S. Department of Commerce, National Technical Information Service, PB-226-217.

Carrigan, P. H., Jr., Dempster, G. R., Jr., and Bower, D. E., 1977, User's guide for U.S. Geological Survey rainfallrunoff models-revision of Open-File Report 74-33: U.S. Geological Survey Open-File Report 77-884, 16 sec.

Dawdy, D. R., Lichty, R. W., and Bergmann, J. M., 1972, A rainfall-runoff simulation model for estimation of flood peaks for small drainage basins: U.S. Geological Survey Professional Paper 506-B, $28 \mathrm{p}$.

Draper, N. R., and Smith, H., 1967, Applied regression analysis: New York, John Wiley and Sons, $407 \mathrm{p}$.

Fenneman, N. M., 1938, Physiography of eastern United States: New York, McGraw-Hill Book Co., 691 p.

Green, A. R., 1964, Magnitude and frequency of floods in the United States: U.S. Geological Survey Water-Supply Paper 1671, pt. 1-A, 260 p.

Hardison, C. H., 1971, Prediction error of regression estimates of streamflow characteristics at ungaged sites: U.S. Geological Survey Professional Paper 750-C, p. 228-236.
Johnson, C. G., 1970, A proposed streamflow data program for central New England: U.S. Geological Survey open-file report,38 p.

Johnson, C. G., and Tasker, G. D., 1974, Progress report on flood magnitude and frequency of Massachusetts streams: U.S. Geological Survey Open-File Report 74-131, 41 p.

Kinnison, H. B., and Colby, B. R., 1944, Flood formulas based on drainage basin characteristics: American Society of Civil Engineers Proceedings, v. 70, no. 3, p. 267-294.

Kirby, W. H., 1979, Annual flood frequency analysis using U.S. Water Resources Council Guidelines (Program J407), in WATSTORE National Water Data Storage and Retrieval System User's Guide, volume 4, chapter I, section C: U.S. Geological Survey Open-File Report 79-1336-I.

Knox, C. E., and Johnson, C. G., Jr., 1965, Flood frequency formulas for Massachusetts: U.S. Geological Survey openfile report, $10 \mathrm{p}$.

Knox, C. E., and Nordenson, T. J., 1955, Average annual runoff and precipitation in the New England-New York area: U.S. Geological Survey Hydrologic Investigations Atlas HA-7, 6 p.

Massachusetts Department of Environmental Management, Division of Water Resources, 1979a, Inventory of existing re- 
servoir sites, Charles study area: Massachusetts Department of Environmental Management, Division of Water Resources, 24 p.

$1979 \mathrm{~b}$, Inventory of existing reservoir sites, Merrimack study area: Massachusetts Department of Environmental Management, Division of Water Resources, 33 p.

Myer, A. F., 1928, Elements of hydrology, second edition: New York, John Wiley and Sons, Inc., 522 p.

Potter, W. D., 1957, Peak rates of runoff in the New England Hill and Lowland area: U.S. Department of Commerce, Washington, D.C.

Rosenbrock, H. H., 1960, An automatic method of finding the greatest or the least value of a function: Computer Journal, v. 3, p. 175-184.

Thomson, M. T., Gannon, W. B., Thomas, M. P., Hayes, G. S., and others, 1964, Historical floods in New England: U.S. Geological Survey Water-Supply Paper 1779-M, $105 \mathrm{p}$.

Tice, R. H., 1968, Magnitude and frequency of floods in the United States, pt. 1-B: U.S. Geological Survey Water-Supply Paper 1672, $585 \mathrm{p}$.

U.S. Department of Agriculture, Soil Conservation Service, 1968, Interim memorandum no. 1-water and related land resources of the upper Charles River tributaries with supplements: U.S. Department of Agriculture, Soil Conservation Service.

1969, A study of potential reservoir sites, Housatonic study area with supplements: U.S. Department of Agriculture, Soil Conservation Service.
1970-76, Inventory of potential and existing reservoir sites in the following study areas with supplements (Merrimack, 1970; Neponset, 1970; Thames, 1971; Parker and North Shore, 1971; Nashua, 1972; Deerfield, 1972; Chicopee, 1973; Taunton and Narragansett Bay, 1974; Ipswich, 1974; Millers, 1974; Northern, Central, and Southern Connecticut Valley, 1975; South Shore, Cape Cod, and Buzzards Bay and Islands, 1975; Blackstone, 1975; Westfield, 1975; Farmington, 1976; Hudson, 1976; Sudbury, Assabet, and Concord, 1976): U.S. Department of Agriculture, Soil Conservation Service.

U.S. Geological Survey, 1975, Water resources data for Massachusetts, New Hampshire, Rhode Island, and Vermont, 1974, 429 p.

U.S. Water Resources Council, 1977, Guidelines for determining flood flow frequencies: Water Resources Council Bulletin no. 17A (revised June 1977), 26 p., 14 app.

U.S. Weather Bureau, 1955, Rainfall intensity-duration-frequency curves: U.S. Weather Bureau Technical Paper no. $25,53 \mathrm{p}$.

1959a, Climates of the states, Massachusetts: U.S. Weather Bureau, Climatography of the United States, Paper no. 60-19, $20 \mathrm{p}$.

$1959 \mathrm{~b}$, Rainfall intensity-frequency regime, northeastern United States: U.S. Weather Bureau Technical Paper no. $29,35 \mathrm{p}$.

1959c, Evaporation maps for the United States: U.S. Weather Bureau Technical Paper no. 37, 18 p., 5 pl.

Wandle, S. W., Jr., 1977, Estimating the magnitude and frequency of floods on natural-flow streams in Massachusetts: U.S. Geological Survey Water-Resources Investigations Open-File Report 77-39, 26 p. 


\section{Metric Conversion Factors}

The following factors can be used to convert inch-pound units to International System of Units (SI).

$\begin{array}{rcl} & \text { Length } & \\ \text { inch (in) } & 25.4 & \text { millimeter }(\mathrm{mm}) \\ \text { foot }(\mathrm{ft}) & 0.305 & \text { meter }(\mathrm{m}) \\ \text { mile }(\mathrm{mi}) & 1.61 & \text { kilometer }(\mathrm{km}) \\ & \text { Area } & \\ & & \\ \text { square mile }\left(\mathrm{mi}^{2}\right) & 2.59 & \text { square kilometer }\left(\mathrm{km}^{2}\right) \\ & \text { Volume } & \\ & 0.02832 & \text { cubic meter per second }\left(\mathrm{m}^{3} / \mathrm{s}\right) \\ \text { cubic foot per second }\left(\mathrm{ft}^{3} / \mathrm{s}\right) & 0.01093 & \begin{array}{c}\text { cubic hectometers per square } \\ \text { million cubic feet per square }\end{array} \\ \text { mile }\left(\mathrm{Mft}^{3} / \mathrm{mi}^{2}\right) & & \\ & \text { Slope } & \\ & 0.189 & \text { meter per } \mathbf{k i l o m e t e r}(\mathrm{m} / \mathrm{km})\end{array}$

